\title{
Further evidence of important environmental information content in red-to-green ratios as depicted in paintings by great masters
}

\author{
C. S. Zerefos ${ }^{1,2}$, P. Tetsis ${ }^{1}$, A. Kazantzidis ${ }^{3}$, V. Amiridis ${ }^{4}$, S. C. Zerefos ${ }^{5}$, J. Luterbacher $^{6}$, K. Eleftheratos $^{7}$, \\ E. Gerasopoulos ${ }^{2,8}$, S. Kazadzis ${ }^{8}$, and A. Papayannis ${ }^{9}$ \\ ${ }^{1}$ Academy of Athens, Athens, Greece \\ ${ }^{2}$ Navarino Environmental Observatory (N.E.O.), Messinia, Greece \\ ${ }^{3}$ Laboratory of Atmospheric Physics, Physics Department, University of Patras, Greece \\ ${ }^{4}$ Institute of Astronomy, Astrophysics, Space Application and Remote Sensing, National Observatory of Athens, Greece \\ ${ }^{5}$ Hellenic Open University, Patras, Greece \\ ${ }^{6}$ Department of Geography, Climatology, Climate Dynamics and Climate Change, Justus Liebig University of Giessen, \\ Giessen, Germany \\ ${ }^{7}$ Faculty of Geology and Geoenvironment, University of Athens, Greece \\ ${ }^{8}$ Institute of Environmental Research and Sustainable Development, National Observatory of Athens, Greece \\ ${ }^{9}$ National Technical University of Athens, Athens, Greece \\ Correspondence to: C. S. Zerefos (zerefos@geol.uoa.gr)
}

Received: 11 November 2013 - Published in Atmos. Chem. Phys. Discuss.: 18 December 2013

Revised: 21 February 2014 - Accepted: 1 March 2014 - Published: 25 March 2014

\begin{abstract}
We examine sunsets painted by famous artists as proxy information for the aerosol optical depth after major volcanic eruptions. Images derived from precision colour protocols applied to the paintings were compared to online images, and found that the latter, previously analysed, provide accurate information. Aerosol optical depths (AODs) at $550 \mathrm{~nm}$, corresponding to Northern Hemisphere middle latitudes, calculated by introducing red-to-green $(\mathrm{R} / \mathrm{G}) \mathrm{ra}$ tios from a large number of paintings to a radiative transfer model, were significantly correlated with independent proxies from stratospheric AOD and optical extinction data, the dust veil index, and ice core volcanic indices. AODs calculated from paintings were grouped into 50-year intervals from 1500 to 2000 . The year of each eruption and the 3 following years were defined as "volcanic". The remaining "non-volcanic" years were used to provide additional evidence of a multidecadal increase in the atmospheric optical depths during the industrial "revolution". The increase of AOD at $550 \mathrm{~nm}$ calculated from the paintings grows from 0.15 in the middle 19th century to about 0.20 by the end of the 20th century. To corroborate our findings, an experiment was designed in which a master painter/colourist painted successive sunsets during and after the passage of Saharan
\end{abstract}

aerosols over the island of Hydra in Greece. Independent solar radiometric measurements confirmed that the master colourist's R / G ratios which were used to model his AODs, matched the AOD values measured in situ by co-located sun photometers during the declining phase of the Saharan aerosol. An independent experiment was performed to understand the difference between $\mathrm{R} / \mathrm{G}$ ratios calculated from a typical volcanic aerosol and those measured from the mineral aerosol during the Hydra experiment. It was found that the differences in terms of $\mathrm{R} / \mathrm{G}$ ratios were small, ranging between $-2.6 \%$ and $+1.6 \%$. Also, when analysing different parts of cloudless skies of paintings following major volcanic eruptions, any structural differences seen in the paintings had not altered the results discussed above. However, a detailed study on all possible sources of uncertainties involved (such as the impact of clouds on R/G ratios) still needs to be studied. Because of the large number of paintings studied, we tentatively propose the conclusion that regardless of the school, red-to-green ratios from great masters can provide independent proxy AODs that correlate with widely accepted proxies and with independent measurements. 


\section{Introduction}

In the paper by Zerefos et al. (2007), the monochromatic ratios between red, green and blue colours, in paintings before, during and after large volcanic eruptions were examined. In that study, digital images from 554 paintings were downloaded from the websites of several art galleries and museums. These images were processed to derive ratios between the intensities of monochromatic colours. For the calculation of the R/G ratios only the parts of the sky over the field of view of the artist near the horizon avoiding clouds were analysed. The average values and the standard deviation of $\mathrm{R} / \mathrm{G}$ ratio for each painting were presented in Appendix B of Zerefos et al. (2007). In that study, the mean error value was 0.014 due to the variability of $\mathrm{R} / \mathrm{G}$ ratios within the paintings/images. That variability and how it could affect the estimated AOD values for different aerosol conditions and solar zenith angles was examined. The uncertainty found was less than 0.05 for small optical depths and smaller SZA $\left(70^{\circ}\right)$. The error increased with increasing AOD and SZA $\left(85^{\circ}\right)$ and could be as large as 0.18 for AOD values exceeding 0.5 . The study by Zerefos et al. (2007) concluded that regardless of the school or the style of the painter, the R/G ratios at low solar elevation angles, correlated well to the modelled aerosol optical depth (AOD) values following large volcanic eruptions. After its publication we were faced with the dilemma that the various digital images available at the above-mentioned websites were not necessarily accurate representations of the true colour profile reproduction, because they were not created following a single colour profile protocol and thus, we decided to revisit the issue.

In this work we provide new evidence that our earlier results, based on $\mathrm{R} / \mathrm{G}$ ratios to estimate and model AODs in paintings are robust, a hypothesis which is supported using the following three methods: firstly, by correlating the available $\mathrm{R} / \mathrm{G}$ ratios from the above-mentioned public websites with the same ratios from their respective high quality colour profile protocols. A colour profile protocol is the protocol (set of instructions) used to accurately translate colour through different devices. In our work a colour profile was absolutely necessary so that the scanned paintings retained their original colour information when distributed through digital means. Also by having the colour profile along with calibrated scanners it was possible to compare paintings from other colourists without any uncertainty by differences due to colour translation. Secondly, by comparing our earlier results of AODs based on art, with results and indices from other proxies (ice cores, pyrheliometric and other data) which cover the past 500 years (Lamb, 1970, 1977, 1983; Sato et al., 1993; Stothers, 1996, 2001; Robertson et al., 2001; Gao et al., 2008; Crowley and Unterman, 2013). Thirdly, by performing an experiment involving the creation of sunset paintings and then measuring the ratios of the art piece with collocated AOD measurements actually recorded in the atmosphere during and after the passage of a Saharan dust event.

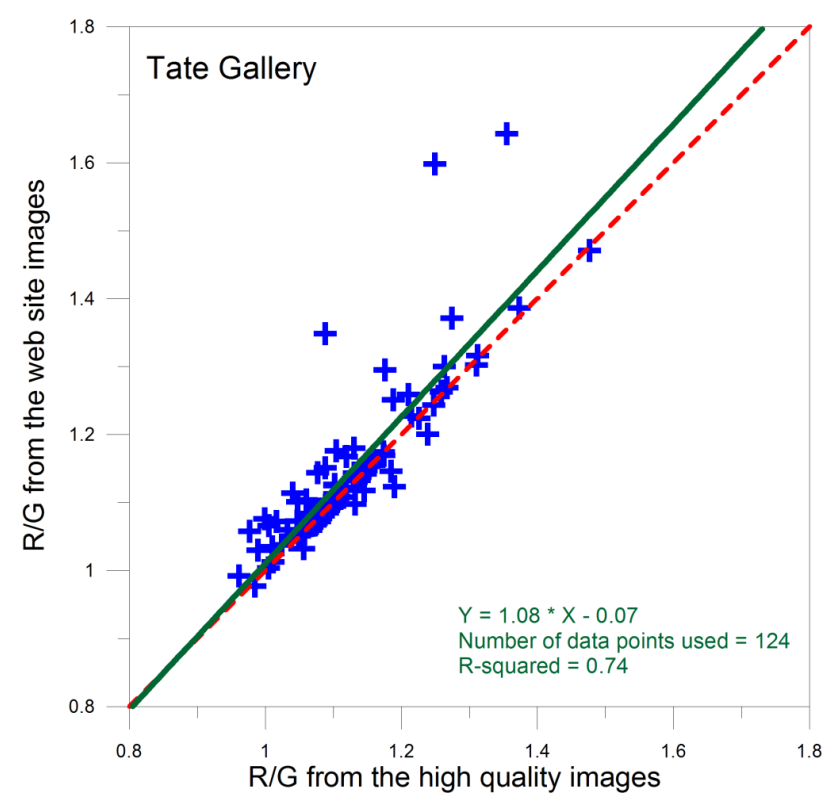

Fig. 1. R/G ratios derived from painting digital images from web site (low resolution) vs. R/G ratios for the same paintings obtained through colour profile protocol (high resolution) at the Tate Gallery. The corresponding linear best fit (green line) and the perfect correlation line (dashed red line) are also shown. The values correspond to the 124 landscape paintings listed in Appendix A.

More specifically, we have organized an experimental campaign where Panayiotis Tetsis ${ }^{1}$ (a well-known Greek landscape painter and colourist) painted the sunsets at the Hydra island in the Aegean Sea, during and after the passage of a Saharan dust event on the 19 and 20 June 2010. During the creation of the paintings, we performed simultaneous measurements of the evolution of the observed AODs and the actual meteorological conditions were carefully monitored. The results from these three methods are described below.

\section{Comparison between high and low quality digital images of paintings}

As mentioned in the introduction, in an earlier study (Zerefos et al., 2007) the vast majority of images were analysed from museum web sites which were not created following a rigorous colour profile protocol. The method of painting sampling and an analysis of the corresponding uncertainties is described in the study by Zerefos et al. (2007). Since it was not possible to obtain high quality images of paintings from all galleries, we focus here on the subset kept at the Tate Gallery in the United Kingdom (UK). At this gallery we found 124 digital images of paintings (with a 300 dpi resolution, RGB, 8 bit compressed jpeg format files) which were also analysed in our earlier work (listed in Appendix A).

\footnotetext{
${ }^{1}$ http://www.wikipaintings.org/en/panayiotis-tetsis
} 


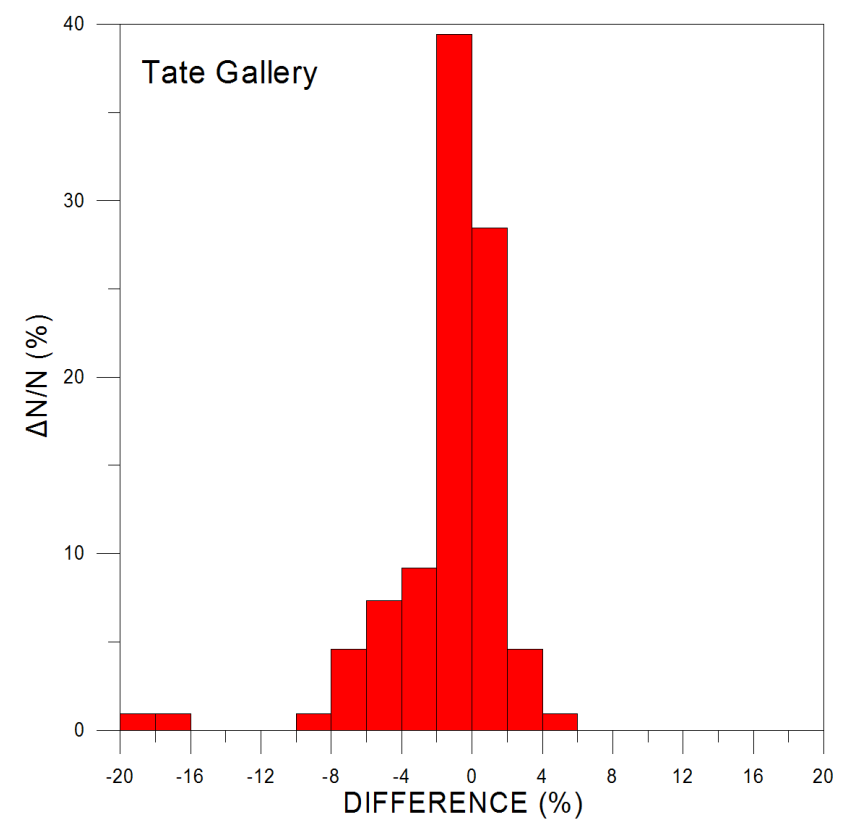

Fig. 2. Distribution of the relative differences (in \%) between the $\mathrm{R} / \mathrm{G}$ ratios derived from the high- and the low-resolution images from 124 landscape sunsets at the Tate Gallery (listed in Appendix A).

Figure 1 shows the results of the $R / G$ values retrieved from these high quality images in comparison to the ratios (calculated for the same paintings) from the website images, using the same methodology, as described in Zerefos et al. (2007). As can be seen from Fig. 1, the difference between the $\mathrm{R} / \mathrm{G}$ values of the lower and higher resolution digital images stays within $\pm 4 \%$ for almost all paintings. Very few exceptions with overestimations correspond to solar zenith angles exceeding $90^{\circ}$.

This result is clearly seen in Fig. 2 which shows the percent distribution of the relative differences between the $\mathrm{R} / \mathrm{G}$ ratios derived from the high vs. the low resolution $124 \mathrm{im}-$ ages from the Tate Gallery.

Additionally, an independent sample of 186 landscape paintings of high quality/resolution $(10000 \times 10000$ pixel images), covering the 1500-1900 time period, obtained from the National Gallery, London, calibrated using the Gretag Macbeth 24-patch colour rendition chart (Saunders et al., 2002; McCamy et al., 1976). None of these paintings has been studied in our earlier study because they did not fulfil the selection criteria set, that is, for representing sunsets and the possibility for direct or indirect measurements through clear shades, to facilitate the estimate of solar zenith angle, pertaining to each painting.

The high-quality/resolution images obtained directly from the National Gallery were next compared to their corresponding low-quality/resolution images obtained from the website (http://www.nationalgallery.org.uk/cgi-bin/WebObjects.

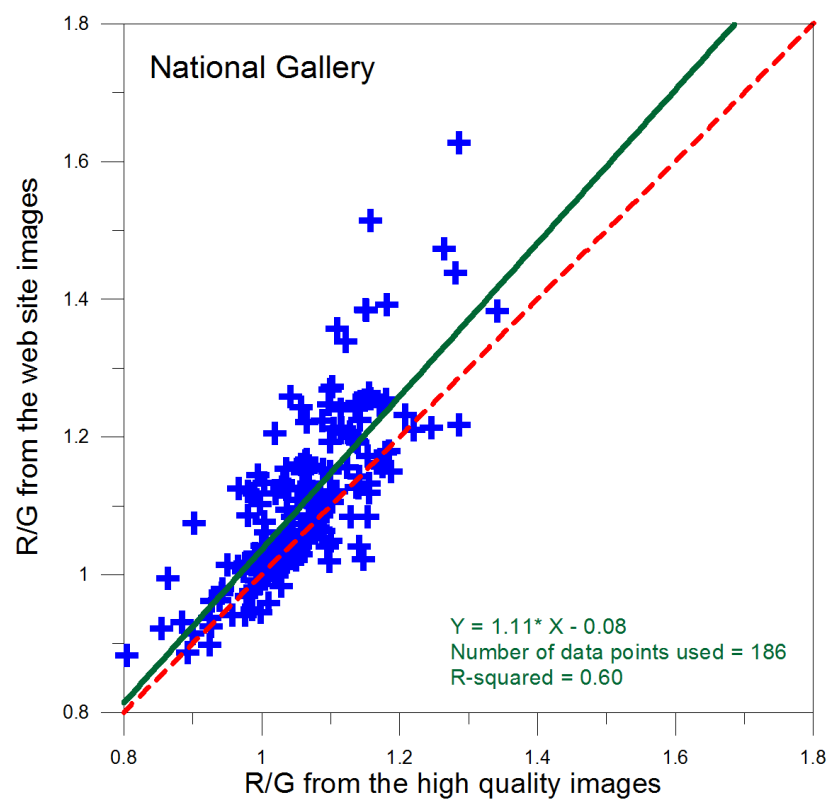

Fig. 3. Results from a completely independent sample of paintings. $\mathrm{R} / \mathrm{G}$ ratios derived from painting digital images from the web site (low resolution) vs. the same $\mathrm{R} / \mathrm{G}$ ratios from high resolution digital images at the National Gallery, London. The corresponding linear fit (green line) and the $y=x$ line (dashed red line) are also shown. The values correspond to 186 landscape paintings, which were not used in the early study by Zerefos et al. (2007), as described in the text.

dll/CollectionPublisher) to test further the results obtained from the Tate Gallery comparisons shown in Figs. 1 and 2.

The retrieved $\mathrm{R} / \mathrm{G}$ values of these images are shown in Fig. 3, from which we see that on the average, the R/G values are overestimated by $0.04 \pm 0.08$. This result is in agreement with the results from the Tate Gallery sample of paintings and a tentative result is that the overestimation is larger (up to 0.3) deviating from the linear fit for the higher R/G values. At any rate, the correlation coefficients are still highly significant (99\% confidence level). It should be noted here that all images in this study were processed with the "nip2" software (e.g. http://www.vips.ecs. soton.ac.uk/index.php?title=Nip2) which comfortably works with multi-gigabyte images. A special work script has been created in order to calculate the average R/G values of the sky from each painting, as derived from the low- and highquality/resolution images.

\section{Other factors that might affect the $\mathrm{R} / \mathrm{G}$ ratios from paintings}

When trying to estimate a number that would describe the true colour at given solar zenith angle during a sunset, there are several factors that are important sources of uncertainty. Among them are the coatings, the degradation of colour due 
to ageing, the unknown systematic practices used by the painters, the mood of the painter and the different styles of schools. However, we have to keep in mind that the earlier and present findings, of a relation between high aerosol content at sunsets, were not based on true colours but confined only to the case of the R/G ratios. The different factors affecting the true colours mentioned above, being either random or systematic, may also affect the R/G ratios. Although this may be true for an individual painting, the statistics presented here show that when a large number of paintings by different painters are considered, these uncertainties could be much reduced. This is supported by the signal-to-noise ratio analysis of the statistical standard errors discussed in the introduction and in Zerefos et al. (2007). In addition, we have searched for a possible impact of structural differences. We provide here examples of paintings with and without structural differences following two major volcanic eruptions namely Tambora (1815) and Krakatau (1883). The calculated $\mathrm{R} / \mathrm{G}$ ratios in parts of the sky give a similar result in which the differences are small, anyhow smaller than the standard errors we have encountered in this work (see paintings in Appendix C). Therefore, we have to tentatively assume that the impact of structural differences when studying $R / G$ ratios in parts of the sky of the painting are small. We note here that we have made every possible effort to avoid measuring R/G ratios in the presence of clouds. It appears that $R / G$ ratios as measured in this work somehow remind us of the ratios of solar irradiance in different wavelengths which are used in spectrophotometers to measure columnar gases in the atmosphere. In these spectroradiometers the noise introduced by aerosols and other factors related to scattering and related effects are indeed cancelled out and this is how we obtained the long series of total ozone, total sulfur dioxide, and total nitrogen dioxide with remarkably small standard error. We think that the reduction of errors when using $\mathrm{R} / \mathrm{G}$ ratios provides useful information on the overhead aerosol content which correlates well when averaged with other proxies and/or with real AOD measurements as was the case with the Hydra experiment, discussed in paragraph 5.

In our study, a detailed quantification of each source of uncertainty was not possible except for the effects of quality in digitization of the paintings, structural differences and the solar zenith angle. Potential sources of uncertainty could be the atmospheric/aerosol related dynamics which affect the magnitude of the impact of each volcano in the area under study (of the painter) as well as the impact of cloudiness on the depicted R/G. We believe any effects from clouds have been avoided by trying to confine our R/ G "measurements" to the cloudless parts of the sky in each painting. Following the above discussion and since our goal in this part of the manuscript was focused on the validation of the volcanic eruption effect and not on the actual quantification of the volcanic aerosol in the painting area, we believe that correlation coefficients with the mentioned proxies provide evidence that this goal has been achieved.

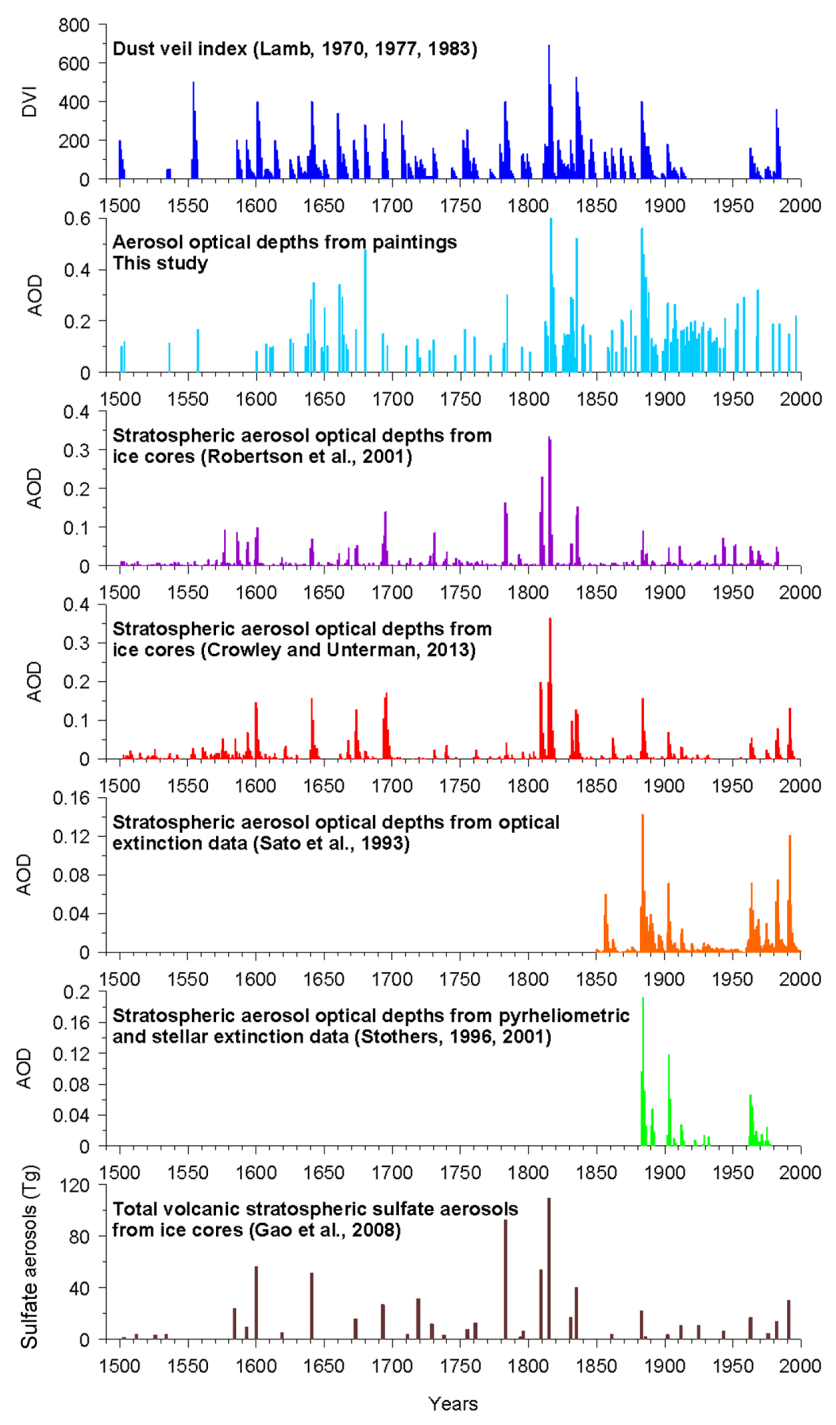

Fig. 4. Aerosol optical depth and other proxy indices during the past 500 years from different proxies (see text).

\section{Atmospheric optical depths based on known proxies and on $R / G$ ratios of paintings in the past 500 years}

The earlier estimates of the aerosol optical depth at $550 \mathrm{~nm}$ (based on R/G calibrated ratios from paintings) and the radiative transfer model by Mayer and Kylling (2005) and Mayer and Emde (2007), were used to compile an independent time series with AODs during 1500-2000. Additionally, the time series of AODs calculated from paintings has been divided into 50-year intervals from 1500 to 2000 . The year of each eruption and the 3 following years were defined as "volcanic". The remaining "non-volcanic" years were used to calculate the average AOD value pertaining to these years corresponding to Northern Hemisphere mid latitudes. This paper is based on evidence by western painters and colourists. The type of art is typical to western European 
schools so it was inevitable to have more paintings in European countries. Nevertheless, the paper focuses on big volcanic eruptions that have an effect over the entire planet atmosphere, so the evidence could be noticed in most parts of the world. This long-term data set of AODs is compared to other independent proxies as shown in Fig. 4. Detailed information on those proxies can be found in the primary literature by Lamb (1970, 1977, 1983), Sato et al. (1993), Stothers (1996, 2001), Robertson et al. (2001), Gao et al. (2008) and Crowley and Unterman (2013). Using the data shown in Fig. 4 , we found that the correlation coefficients between other proxy indices and the estimated AODs from the R/G ratios from paintings are statistically significant (Table 1). Appendix D presents the data used in the calculations shown in Table 1. The reader is also referred to the precision by which the extreme AODs between paintings and proxies during large volcanic eruptions match in most cases. In particular, in 102 cases for which data of both DVI and this study are simultaneously available, DVI spikes are coinciding with AOD spikes from this study at a percentage of $80 \%$ (9 out of 11 cases). As spikes we define the values in both time series that belong in the upper $10 \%$ range of values. In addition, this study revealed two high AOD cases that do not match with DVI spikes and it is worth noting that both failing cases succeeded a period of two consecutive years with spikes in both indices.

Total sulfate is the total measured sulfate concentration in $\mathrm{ppb}$ in the core, as resulted from deposition either from the stratosphere (volcanic) or the troposphere (anthropogenic and other biogenic sources), as described by Zielinski et al. (1996) and Robertson et al. (2001). The presented values do not refer directly to the atmospheric concentration, but rather to the deposition on ice which, however, is related to ambient concentrations. The values of calculated index of total sulfate from Greenland ice cores (Zielinski, 1995; Zielinski et al., 1996) and the longer time series of stratospheric AOD (Robertson et al., 2001) were grouped in 50-year time intervals with the same procedure described above for AODs calculated from paintings. The three data sets are presented in Fig. 5. We note here the point raised by Robertson et al. (2001) that the last 150-year increase in total sulfate from ice cores was hypothesized to be the result of tropospheric anthropogenic sulfate deposition. The point raised by Robertson et al. that there have been no major volcanic eruptions between 1900 and 1960, needs some clarification. Indeed in the list of major volcanic eruptions in the past 500 years (Appendix B after Ammann and Naveau, 2003; Robock, 2000), we can see that based on VEI two eruptions, Santa Maria (1903) and Katmai (1912) have been classified with VEI 6. However, VEI is known to be not a good index of stratospheric sulfate loading since it measures the explosivity of a volcano and not its stratospheric injection. A good example is the 1980 St. Helen's eruption, with a VEI of 5 but no stratospheric or climatic impact (A. Robock, personal communication, 2014). Stratospheric injection is important to ensure

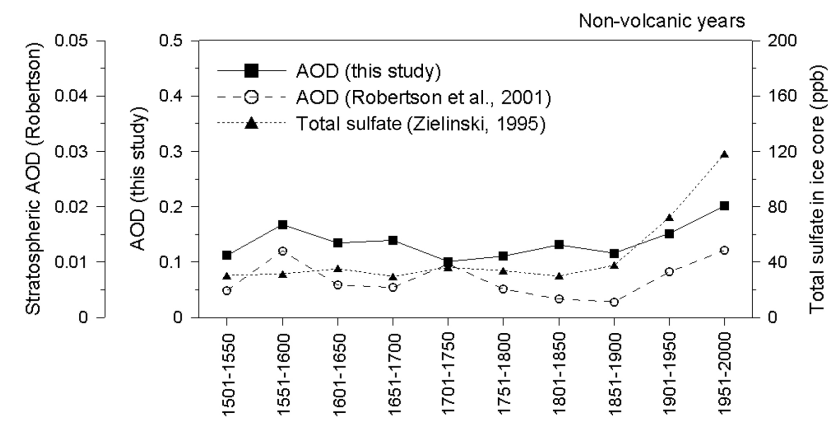

Fig. 5. Total AOD from paintings and in the stratosphere and total sulfate in Greenland ice core (in ppb) averaged over 50-year intervals for "non-volcanic" years during the period 1500-2000 AD.

its global or hemispheric effects. From the above discussion it can be proposed that compared to the pre-industrial period, the industrial period shows higher painting-derived aerosol content, in agreement with what is expected from the literature (e.g. Neftel et al., 1985; Robock and Free, 1995; Robertson et al., 2001; Forster et al., 2007; Wild, 2012).

\section{A live case: the Hydra experiment}

To corroborate our findings, a dedicated experimental campaign has been organized and implemented in Greece, aiming to evaluate the $R / G$ retrieval methodology against ground-truth measurements of the aerosol load in terms of AOD values. The well-known colourist and landscape painter Panayiotis Tetsis (http://www.wikipaintings.org/en/ panayiotis-tetsis) kindly offered to paint in real time a number of sunsets at the island of Hydra. As the great master was painting, a suite of ground-based aerosol measurements were collected, mainly by means of collocated sun photometry equipment. The master colourist had no idea of the passage of a Saharan dust cloud over Hydra.

\subsection{Experiment organization and instrumentation}

The experiment was conducted in Hydra, the painter's home base. Hydra is an island located in the Aegean Sea $\left(37.21^{\circ} \mathrm{N}\right.$, $\left.23.28^{\circ} \mathrm{E}\right), 80 \mathrm{~km}$ south of Athens, and has a population of about 2000 inhabitants. The size of the island satisfies the main requirement for negligible local aerosol emissions (cars are not allowed in the island). Apart from sea spray particles, that constitute the background aerosol component around the island, the only case of regional pollution influence is under northerly winds when the island is within the outflow of pollution from Athens. In the case of winds from southerly directions, most of the Athenian sources of aerosols do not reach Hydra island.

For the design of the experiment, paintings and measurements during relatively low and high AOD cases was the main goal. According to Gerasopoulos et al. (2011), 
Table 1. Correlation coefficients between volcanic aerosol indices and AOD proxies shown in Fig. 4.

\begin{tabular}{|c|c|c|c|c|c|c|c|}
\hline $1500-2000$ & DVI & $\begin{array}{r}\text { AOD } \\
\text { (this study) }\end{array}$ & $\begin{array}{r}\text { AOD } \\
\text { (Robertson) }\end{array}$ & $\begin{array}{r}\text { AOD } \\
\text { (Crowley and } \\
\text { Unterman) }\end{array}$ & $\begin{array}{l}\text { AOD } \\
\text { (Sato) }\end{array}$ & $\begin{array}{r}\text { AOD } \\
\text { (Stothers) }\end{array}$ & $\begin{array}{r}\text { Sulfate } \\
\text { (Gao) }\end{array}$ \\
\hline DVI & 1 & & & & & & \\
\hline AOD (this study) & $\mathbf{0 . 8 5}[102]$ & 1 & & & & & \\
\hline AOD (Robertson) & 0.65 [227] & $\mathbf{0 . 5 8}[118]$ & 1 & & & & \\
\hline AOD (Crowley and Unterman) & $0.57[154]$ & $0.54[74]$ & $\mathbf{0 . 8 0}[239]$ & 1 & & & \\
\hline AOD (Sato) & $0.65[66]$ & $\mathbf{0 . 5 5}[61]$ & $\mathbf{0 . 5 7}[126]$ & $0.91[78]$ & 1 & & \\
\hline AOD (Stothers) & (*) [29] & (*) [21] & $\mathbf{0 . 8 3}[37]$ & (*) [29] & $0.92[38]$ & 1 & \\
\hline Sulfate (Gao) & (*) [23] & (*) [14] & 0.88 [33] & (*) [24] & (*) [11] & (*) [6] & 1 \\
\hline
\end{tabular}

Bold: all the above correlations are significant at the $99 \%$ confidence level $(t$ test). * missing correlations are those possessing less than 30 years of data.

In brackets: number of pairs.

the typical background AOD for the area is $0.12-0.13$ corresponding to long and fast trajectories from westerly to northerly directions, with origin from high altitudes over the Atlantic. Higher aerosol loading over the area is related to the advection of dust particles from desert and arid locations of North Africa and is in the AOD range of 0.3-0.4. The most frequent season for dust outbreaks over the eastern Mediterranean is well documented to be in late spring (e.g. Kalivitis et al., 2007; Gerasopoulos et al., 2011) and early summer (the latter mostly as elevated dust layers; Papayannis et al., 2008).

For the selection of the experiment days, a regional model designed to simulate and forecast the atmospheric cycle of mineral dust aerosol over the campaign site was deployed. In particular, forecasts from the BSC-DREAM8b dust regional model were used (Nickovic et al., 2001) and the period finally selected to combine an AOD episode followed by clean conditions and the painter's availability was $19-20$ June 2010.

The instrumentation used for the campaign, included a multi-filter rotating shadowband radiometer (MFR-7 Yankee Env. System Inc., Turner Falls, MA) and a Microtops II sunphotometer (Solar Light Inc., Philadelphia, USA). The MFR7 installed at Hydra was used to perform measurements of the total and diffuse solar irradiance to calculate the direct component of the irradiance (Harrison et al., 1994). MFR7 provided 1 min average measurements and from these the AOD values at $500 \mathrm{~nm}$ was extracted. The instrument performs valid measurements during daytime and under clear sky conditions. The methodology followed for the extraction of the AOD values from direct solar irradiance is thoroughly described in Gerasopoulos et al. (2003). The calibrated handheld sunphotometer (Microtops II) was used to provide the $\mathrm{AOD}$ at $1020 \mathrm{~nm}$, at $10 \mathrm{~min}$ intervals.

\subsection{Experimental Results and discussion}

As mentioned, the experiment took place in Hydra on 19 and 20 June 2010. During the campaign, a Saharan dust event passed over Greece (18-21 June 2010). On these two dates master Tetsis created two successive paintings; before and during sunset on the 19 and two additional paintings at sunset on the next day, 20 June 2010. Although the typical size and vertical profile of the Saharan aerosols differ from the volcanic ones, their effect on solar irradiance and $\mathrm{R} / \mathrm{G}$ close to sunset was proved to be significant because of their relative high values of AOD $(\sim 0.25$ at $500 \mathrm{~nm})$. The Tetsis experiment has initially started as an experiment dedicated to investigate if AOD's can be calculated from such a live study. During the two day experiment the substantial difference between the aerosol condition of the first and the second day provided a more adequate data set, supporting the assumption that a painter is able to reproduce such an aerosol change. Quantitatively it has been proven that this assumption was correct, as analysed in the following. In the next paragraph it will be shown that the Saharan dust outbreak of the 19 June has been found to affect the R/ G ratios of Tetsis' paintings.

The results from the BSC-DREAM8b model simulations of the space and time evolution of the columnar dust loading for the campaign days (19 and 20 June,) are shown in Fig. 6, as isopleths of AODs. Additionally, the wind fields at $3000 \mathrm{~m}$ heights are superimposed, showing clearly a southwestern flow affecting the site in both campaign days. No precipitation or cloudiness prevailed over Greece during the campaign period (Fig. 6 - upper panel), also corroborated by MODIS satellite images (not shown here). A massive transport of dust from the Saharan desert was observed on the 19 June over Greece and western Turkey, while on 20 June the centre of the dust plume moved to the east and spread and declined (Fig. 6 - lower panel). Following the BSC-DREAM8b simulations, the dust load reached maximum columnar concentration values of the order of $0.75 \mathrm{~g} \mathrm{~m}^{-2}$ over the Hydra site on the 19 June.

The model simulations agree with real-time measurements, as shown in Fig. 7 by the time evolution of the observed AOD values on site for 19 and 20 June, measured with MFR-7 and Microtops. As stated before, the local pollution 

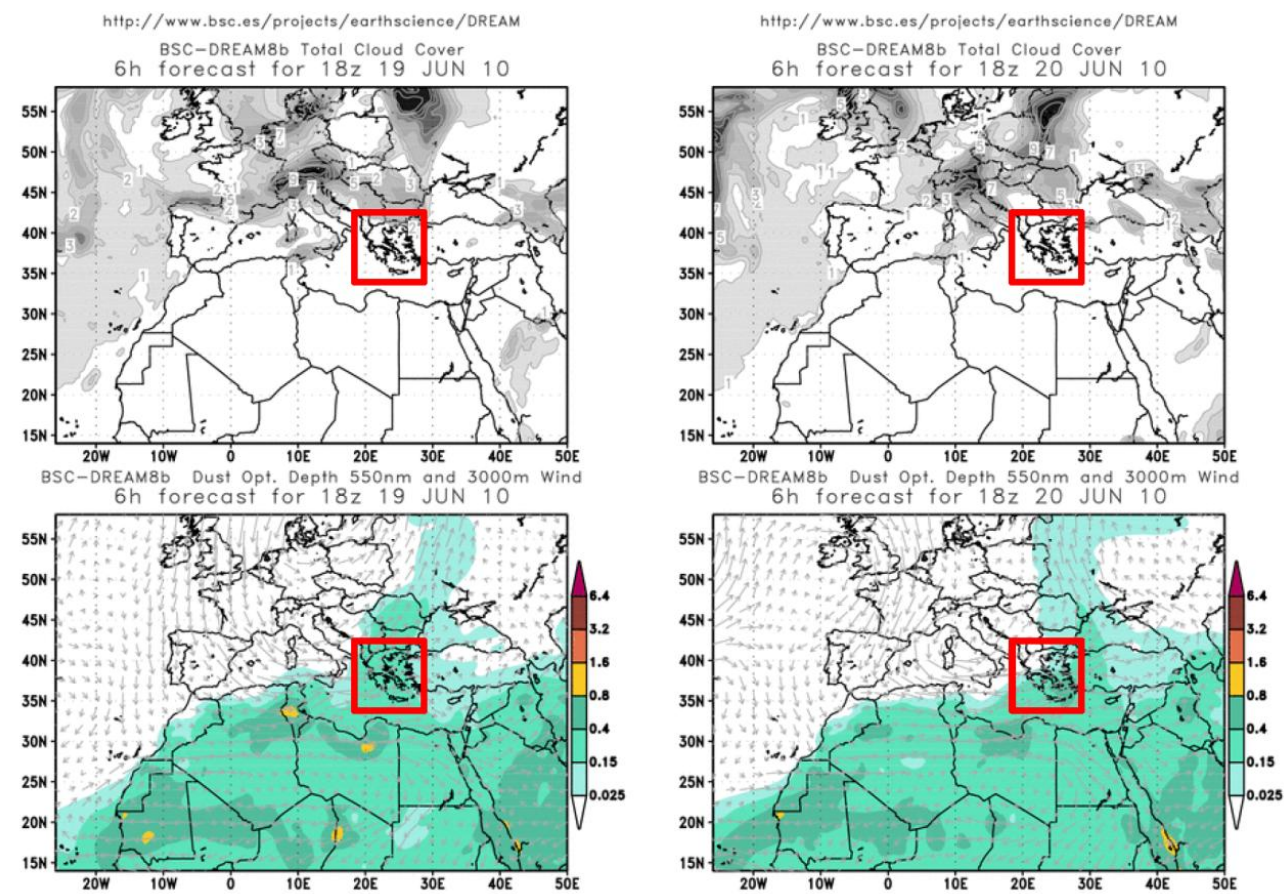

Fig. 6. Dust optical (AOD) depth at $550 \mathrm{~nm}$ and $3000 \mathrm{~m}$ wind fields over Greece for the 19 and 20 June 2010 , as simulated by the BSC/DREAM model (18:00 UTC). The greater area of Greece is indicated by a red-lined rectangle. The island of Hydra is on the centre of this shape.

at Hydra is considered negligible and under southerly flows urban pollution from Athens does not reach the island. The meteorological conditions prevailing during both days (at sunset hours) were similar, namely temperatures between 28 and $30^{\circ} \mathrm{C}$ (slightly higher on the second day) relative humidity between about 45 and $60 \%$, and calm wind conditions $\left(1-2 \mathrm{~m} \mathrm{~s}^{-1}\right)$. The AOD values observed at Hydra, for the most part, can be attributed to the presence of the Saharan dust aerosol and follow the temporal evolution depicted by the dust simulations shown in Fig. 6, from which we see higher AOD values on 19 June and lower on the next day at Hydra. The temporal decay is profound also in the Microtops measurements at $1020 \mathrm{~nm}$, performed at Hydra and shown also in Fig. 7.

Sunphotometric measurements are a trustworthy source for identifying the Saharan dust presence, for which we expect higher AOD values and lower spectral dependences between the multi-wavelength AOD retrievals. This is clearly seen in the data presented in Fig. 7, where higher AODs for 19 June are accompanied by lower spectral dependences between the 500 and $1020 \mathrm{~nm}$ channels. Moreover, the respective Ångström exponents were on average 0.4 on the first day, indicative of coarse dust aerosols and in the range $0.7-1.0$ on the second day, representing a mixture of sea salt particles with low loadings of continental aerosols (see Gerasopoulos et al., 2011, for indicative ranges of Ångström exponents in the area).
Acknowledging the good performance of the BSCDREAM8b model for the days of our campaign, we present in Fig. 8 the simulations of the vertical distribution of $\mathrm{Sa}$ haran dust concentrations over the area for 19 and 20 June 2010. As can be seen from that Figure, large dust concentrations in the lowest one kilometre were observed on the 19 of June, while on the next day the dust concentrations declined significantly, in the boundary layer and in the column as well. We focus mainly on the aerosol load in the planetary boundary layer since this is expected to impact mostly the painter's perception during the late afternoon hours. It is evident that the dust concentrations within the first kilometre are four (4) times higher on 19 June than those simulated on 20 June.

Figure 9 shows the temporal evolution of the MFR-7 AOD values at $550 \mathrm{~nm}$ during the two days of the campaign together with the $\mathrm{R} / \mathrm{G}$ ratios from a digital camera on site and from the high precision digital images (produced by National Gallery, London, with the methodology described in paragraph 2) of Tetsis paintings (Fig. 10) for the two sunset cases (high aerosol and low aerosol over Hydra). The paintings were transported to the National Gallery where the digital protocol analysis was done. On 19 June 2010 (Fig. 9, upper panel), the estimated AOD differences between the paintings and the closest time digital photos is \pm 0.02 . However, a bias of about $30 \%$ is revealed between these and the MFR measurements on the day of the Saharan dust event. In all three types of measurements/estimations, the variability of AOD 


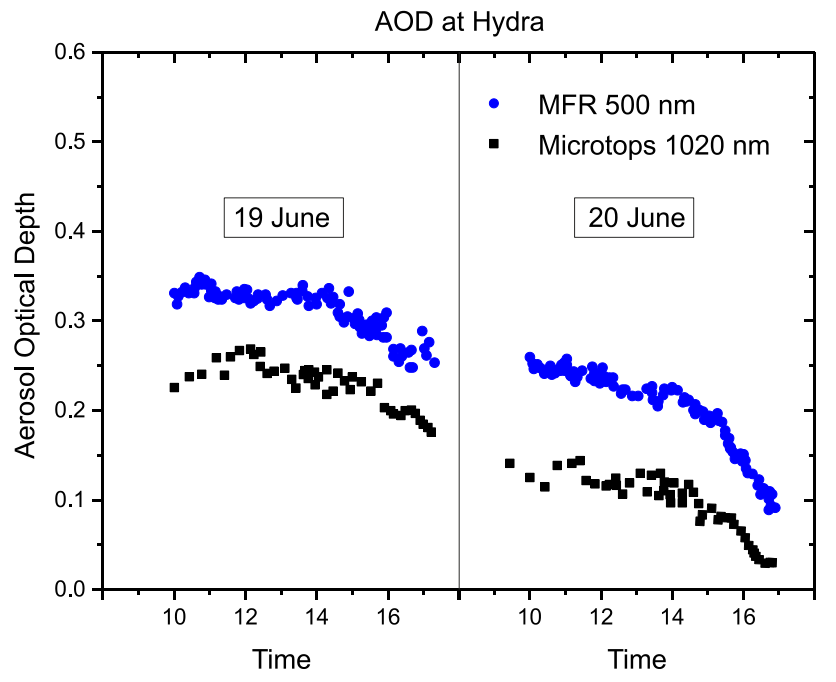

Fig. 7. MFR-7 AOD retrievals at $500 \mathrm{~nm}$ on 19 and 20 June 2010 at Hydra campaign site. Microtops II AOD retrievals at $1020 \mathrm{~nm}$ are superimposed.

with time shows a negative trend as we move from 19 June to the evening of 20 June. On 20 June 2010, the agreement between the digitally derived and the measured AOD values is substantially improved: differences as small as 0.02 can be found. The measured decrease of the AOD values is also successfully represented by the digital estimations. Under each painting a digital photograph at the centre of the time interval it took to paint each painting is displayed for comparison.

Finally, a comparison between the impact of mineral aerosol (Saharan dust) and the impact of a typical volcanic aerosol in terms of RGB is also attempted. The mineral aerosol during the Hydra experiment at $500 \mathrm{~nm}$ was measured to vary close to 0.25 . Therefore, we have made model runs with the volcanic aerosol setting the volcanic AOD case at $500 \mathrm{~nm}$ also equal to 0.25 . Note here that the mean volcanic AOD $(500 \mathrm{~nm})$ in our paintings is very close to that number and is equal to 0.22 . Figure 11 shows the percent difference in $\mathrm{R} / \mathrm{G}$ ratios between the ones measured in the Hydra Saharan dust aerosol profile and a typical modelled volcanic aerosol profile as was used previously in this work. In both cases AOD $(500 \mathrm{~nm})$ was set to 0.25 . The ratios are shown as isopleths in a graph where the position of the sun is fixed at $80^{\circ}$ solar zenith angle. It was quite surprising to see that although both the nature, size and the vertical profiles of the Saharan and the volcanic aerosols differ, their effect on $\mathrm{R} / \mathrm{G}$ overhead ratios in the sky induce so small a difference ranging from a minimum of $-2.6 \%$ to a maximum $+1.6 \%$, depending on the solar zenith angle and the angle relative to the position of the sun.

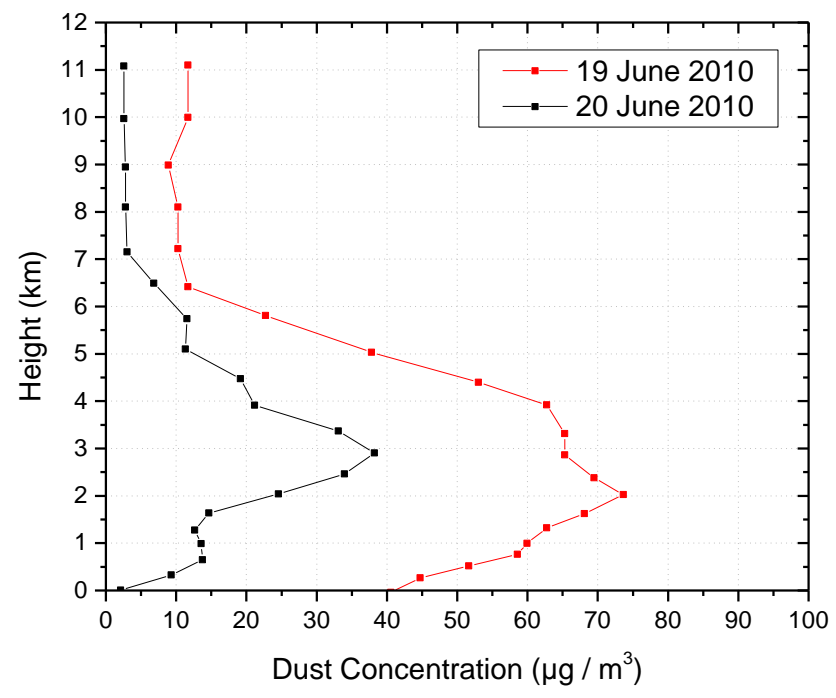

Fig. 8. Vertical distribution of the Saharan dust concentration loading $\left(\mu \mathrm{g} \mathrm{m}^{-3}\right)$ for the 19 and 20 June 2010 , as simulated by the BSC/DREAM model (18:00 UTC).

\section{Conclusions}

Understanding the atmospheric composition of the past centuries is a very difficult task due to scarcity of available measurements. Especially for atmospheric components such as aerosols and their variability over the past 500 years, relevant information is rare (Thornes and Constable, 1999; Grattan, 2006; Zerefos et al., 2007). In this work we have expanded the idea of Zerefos et al. (2007), which used an alternative and indirect way of using the Ångström's law of atmospheric physics that describes the different effects of aerosols on the different wavelengths (colours) of solar light, together with the use of an alternative "database of solar light representations", calculated from paintings by great masters in the past centuries.

At first, a series of paintings by master painters (in the period of 1500-2000) have been revisited and comparisons between digital images of paintings from lower resolution vs. high resolution, derived from high precision protocols, showed similar results, as far as the $\mathrm{R} / \mathrm{G}$ ratios measured at sunsets are concerned. Statistically significant correlation coefficients were found between the $\mathrm{R} / \mathrm{G}$ ratio values retrieved from low quality/resolution and high quality/resolution digital images at a sample of 124 landscape paintings from the Tate Gallery. The earlier estimates of the aerosol optical depth at $550 \mathrm{~nm}$ (based on R/G calibrated ratios from paintings) and the radiative transfer model by Mayer and Kylling (2005) and Mayer and Emde (2007) were used to compile an independent time series with AODs during 1500-2000. The correlation coefficients between other proxy indices and the estimated AODs from the R/ $\mathrm{G}$ ratios from paintings are statistically significant. Also the precision by which the extreme 

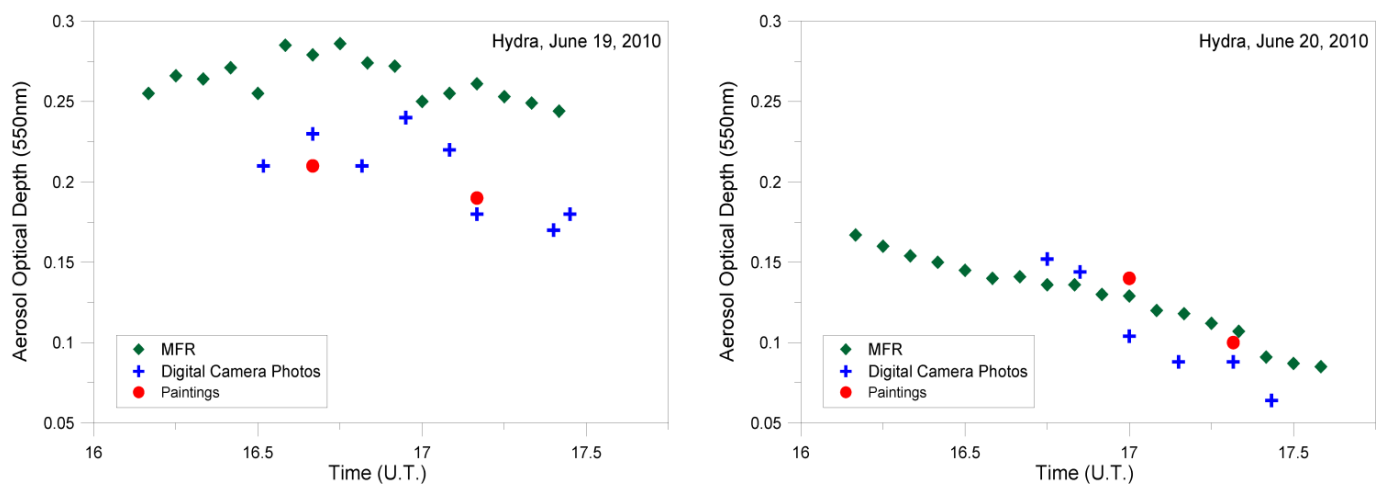

Fig. 9. The AOD values from the MFR measurements, the estimations from the digital images and the calculations from $\mathrm{R} / \mathrm{G}$ ratios of the Hydra sunset paintings for 19 June (left panel, higher aerosol content) and on the 20 June 2010 (right panel, lower aerosol content).
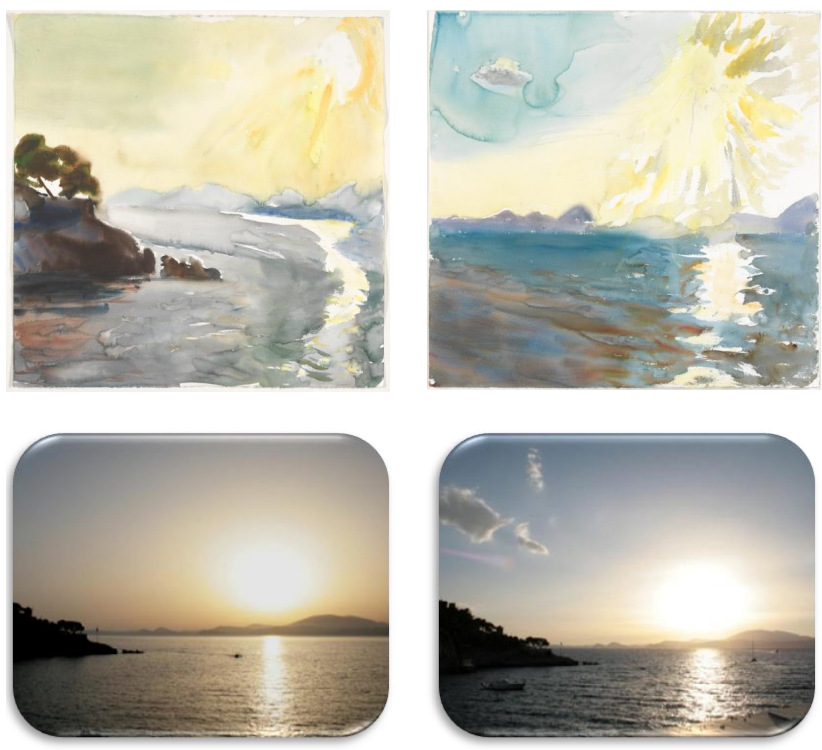

Fig. 10. Upper: digitally compressed paintings by P. Tetsis at the Hydra experiment under higher (left panel) and lower (right panel) AOD conditions. Bottom: digital camera photos of the landscape. Under each painting a digital photograph at the centre of the time interval it took to paint each painting is displayed for comparison (see text).

AODs between paintings and proxies, during large volcanic eruptions, match in most cases.

The comparison between 50-year averages of the AODs (from R/G paintings) with the total sulfate in ice core and the stratospheric AOD, from which the year of known large volcanic eruptions and the three years that followed were excluded, shows that compared to the pre-industrial period, the industrial period had higher aerosol content, as it is well known and expected from independent data sets in the literature (e.g. Neftel et al., 1985; Robock and Free, 1995; Robertson et al., 2001; Forster et al., 2007). Based on the information retrieved from the paintings studied, we estimated this increase to range from 0.15 (middle 19th century) to about 0.20 (by the end of the 20th century).

Finally, to corroborate our findings, an experiment was designed in which a master painter/colourist painted successive sunsets during the passage of a Saharan dust outbreak over our experimental site (island of Hydra, Greece) on 19 and 20 June 2010. The master painter did not know anything about the passage of a Saharan dust event. Our independent sunphotometric measurements at Hydra confirmed that the calculated AOD values from $\mathrm{R} / \mathrm{G}$ ratios measured in the master colourist paintings, matched quite well to the AOD values measured in situ as well as with measurements from a digital camera. It should be noted here that all four watercolours by Panayiotis Tetsis were digitized using the same procedures and standards applied to all works of art photographed by the Photographic Department of the National Gallery, London. These findings point to the conclusion that the experiment provides a new presentation of how a painter, a digital camera and scientific instruments capture changes in $\mathrm{R} / \mathrm{G}$ ratios at high and low aerosol overhead cases.

The new information in the paper can be summarized as follows:

The comparison of high precision with low precision colour protocol images at independent samples of paintings from the Tate and the National Galleries in London strengthen the tentative results proposed in an earlier paper by Zerefos et al. (2007).

AODs from a multi-hundred sample of paintings show statistically significant correlations with independent proxies.

Structural differences in paintings do not seem to alter the above results. The signal-to-noise ratios following volcanic eruptions are statistically significant.

When averaged in 50-year intervals, AODs from paintings in non-volcanic years agree with completely independent data sets with the observed increases of the industrial aerosol in the past 150 years.

$\mathrm{R} / \mathrm{G}$ ratios calculated from different natural profiles such as from volcanic aerosols and Saharan mineral aerosols show 


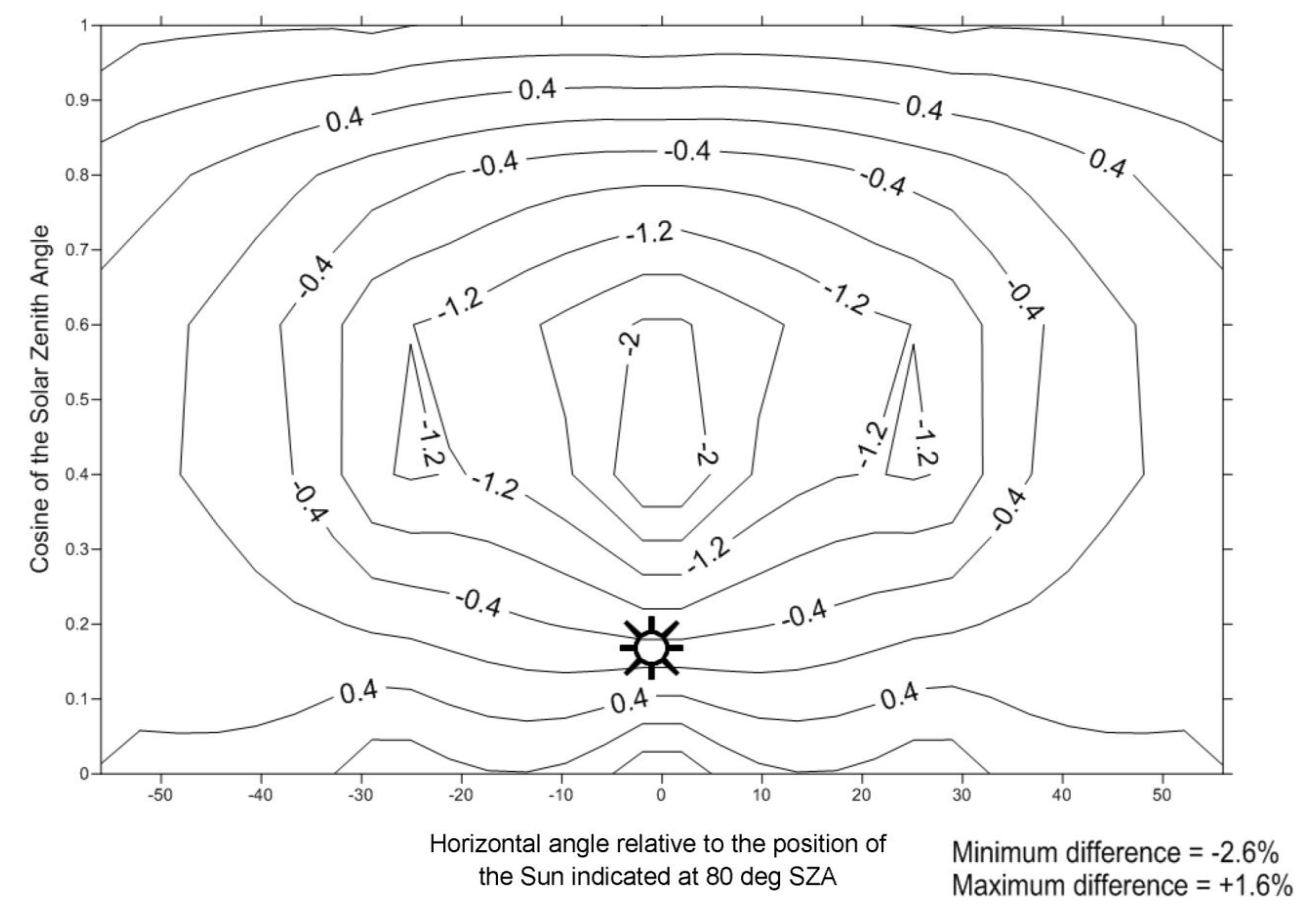

Fig. 11. Percent difference in $R / G$ ratios between the measured at Hydra Sahara dust mineral aerosol profile and a typical modelled volcanic aerosol profile. In both cases AOD $(500 \mathrm{~nm})$ was set to 0.25 .

very small differences. This explains how the experiment performed with an internationally known master colourist arrived at similar results with an increase in $\mathrm{R} / \mathrm{G}$ ratios during the passage of a Saharan dust event.

Regardless of the school, red-to-green ratios from great masters can provide independent proxy AODs that correlate with widely accepted proxies and with independent measurements.

The main conclusion of the paper is that nature speaks to the hearts and souls of the artists. When colouring sunsets the $\mathrm{R} / \mathrm{G}$ ratios perceived by the brain contain important environmental information. It remains to an interdisciplinary community to study further the evidence presented in this research.

Acknowledgements. The LibRadtran team (www.libradtran.org) is acknowledged for providing the model algorithm. The National Gallery is acknowledged for providing 186 landscape paintings of high quality analysis at no charge. BSC-DREAM8b Saharan dust simulations were kindly provided by the Barcelona Supercomputing Centre. The set of high resolution 124 paintings from Tate were purchased at cost and the four watercolour paintings by Panayiotis Tetsis were photographed using the same procedures and standards applied to all works of art photographed by the Photographic Department of the National Gallery, London. We greatly acknowledge the support provided by the Mariolopoulos-Kanaginis Foundation for the Environmental Sciences and the European Union's 7th Framework Programme (FP7/2007-2013) under grant agreement no. 218793 (project title: Monitoring Atmospheric
Composition and Climate). The authors would like to thank Alan Robock and two anonymous reviewers for their valuable comments.

Edited by: N. Mihalopoulos

\section{References}

Ammann, C. and Naveau, P.: Statistical analysis of tropical explosive volcanism occurences over the last 6 centuries, Geophy. Res. Lett., 30, 1210, doi:10.1029/2002GL016388, 2003.

Crowley, T. J. and Unterman, M. B.: Technical details concerning development of a $1200 \mathrm{yr}$ proxy index for global volcanism, Earth Syst. Sci. Data, 5, 187-197, doi:10.5194/essd-5-187-2013, 2013.

Forster, P., Ramaswamy, V., Artaxo, P., Berntsen, T., Betts, R., Fahey, D. W., Haywood, J., Lean, J., Lowe, D. C., Myhre, G., Nganga, J., Prinn, R., Raga, G., Schulz M., and Van Dorland, R.: Changes in Atmospheric Constituents and in Radiative Forcing, in: Climate Change 2007: The Physical Science Basis, Contribution of Working Group I to the Fourth Assessment, Report of the Intergovernmental Panel on Climate Change, edited by: Solomon, S., Qin, D., Manning, M., Chen, Z., Marquis, M., Averyt, K. B., Tignor, M., and Miller, H. L., Cambridge University Press, Cambridge, UK, New York, NY, USA, 996 pp., 2007.

Gao, C., Robock, A., and Ammann, C.: Volcanic forcing of climate over the past 1500 years: An improved ice-core-based index for climate models, J. Geophys. Res., 113, D23111, doi:10.1029/2008JD010239, 2008.

Gerasopoulos, E., Andreae, M. O., Zerefos, C. S., Andreae, T. W., Balis, D., Formenti, P., Merlet, P., Amiridis, V., and 
Papastefanou, C.: Climatological aspects of aerosol optical properties in Northern Greece, Atmos. Chem. Phys., 3, 2025-2041, doi:10.5194/acp-3-2025-2003, 2003.

Gerasopoulos, E., Amiridis, V., Kazadzis, S., Kokkalis, P., Eleftheratos, K., Andreae, M. O., Andreae, T. W., El-Askary, H., and Zerefos, C. S.: Three-year ground based measurements of aerosol optical depth over the Eastern Mediterranean: the urban environment of Athens, Atmos. Chem. Phys., 11, 2145-2159, doi:10.5194/acp-11-2145-2011, 2011.

Grattan, J.: Aspects of Armageddon: an exploration of the role of volcanic eruptions in human history and civilization, Quartern. Int., 151, 10-18, 2006.

Harrison, L., Michalsky, J., and Berndt, J.: Automated multifilter rotating shadow-band radiometer: an instrument for optical depth and radiation measurements, Appl. Optics, 33, 5118-5125, 1994.

Kalivitis, N., Gerasopoulos, E., Vrekoussis, M., Kouvarakis, G., Kubilay, N., Hatzianastassiou, N., Vardavas, I., and Mihalopoulos, N.: Dust transport over the Eastern Mediterranean from TOMS, AERONET and surface measurements, J. Geophys. Res., 112, D03202, doi:10.1029/2006JD007510, 2007.

Lamb, H. H.: Volcanic dust in the atmosphere, with a chronology and assessment of its meteorological significance, Philos. T. R. Soc. Lond., 266, 425-533, 1970.

Lamb, H. H.: Supplementary volcanic dust veil assessments, Climate Monitor, 6, 57-67, 1977.

Lamb, H. H.: Uptake of the chronology of assessments of the volcanic dust veil index, Climate Monitor., 12, 79-90, 1983.

Mayer, B. and Emde, C.: Comment on "Glory phenomenon informs of presence and phase state of liquid water in cold clouds" by Nevzorov, A. N., Atmos. Res., 84, 410-419, 2007.

Mayer, B. and Kylling, A.: Technical note: The libRadtran software package for radiative transfer calculations - description and examples of use, Atmos. Chem. Phys., 5, 1855-1877, doi:10.5194/acp-5-1855-2005, 2005.

McCamy, C. S., Marcus, H., and Davidson, J. G.: A color-rendition chart, J. Appl. Photogr. Eng., 2, 95-99, 1976.

Neftel, A., Beer, J., Oeschger, H., Zurcher, F., and Finkel, R. C.: Sulphate and nitrate concentrations in snow from South Greenland 1895-1978, Nature, 314, 611-613, doi:10.1038/314611a0, 1985.

Nickovic, S., Kallos, G., Papadopoulos, A., and Kakaliagou, O.: A model for prediction of desert dust cycle in the atmosphere, J. Geophys. Res., 106, 18113-18129, doi:10.1029/2000JD900794, 2001.

Papayannis, A., Amiridis, V., Mona, L., Tsaknakis, G., Balis, D., Bösenberg, J., Chaikovski, A., De Tomasi, F., Grigorov, I., Mattis, I., Mitev, V., Müller, D., Nickovic, S., Perez, C., Pietruczuk, A., Pisani, G., Ravetta, F., Rizi, V., Sicard, M., Trickl, T., Wiegner, M., Gerding, M., Mamouri, R. E., D’Amico, G., and Pappalardo, G.: Systematic lidar observations of Saharan dust over Europe in the frame of EARLINET (2000-2002), J. Geophys. Res., 113, D10204, doi:10.1029/2007JD009028, 2008.
Robertson, A., Overpeck, J., Rind, D., Mosley-Thompson, E., Zielinski, G., Lean, J., Koch, D., Penner, J., Tegen, I., and Healy, R.: Hypothesized climate forcing time series for the last 500 years, J. Geophys. Res., 106, 14783-14803, 2001.

Robock, A.: Volcanic eruptions and climate, Rev. Geophys., 38, 191-219, 2000.

Robock, A. and Free, M. P.: Ice cores as an index of global volcanism from 1850 to the present, J. Geophys. Res., 100, 11549$11567,1995$.

Sato, M., Hansen, J. E., McCormick, M. P., and Pollack, J. B.: Stratospheric aerosol optical depths 1850-1990, J. Geophys. Res., 98, 22987-22994, 1993.

Saunders, D., Cupitt, J., White, C., and Holt, S.: The MARC II Camera and the scanning initiative at the national gallery, National Gallery Technical Bulletin, 23, 76-82, 2002.

Stothers, R. B.: Major optical depth perturbations to the stratosphere from volcanic eruptions: pyrheliometric period 1881-1960, J. Geophys. Res., 101, 3901-3920, 1996.

Stothers, R. B.: Major optical depth perturbations to the stratosphere from volcanic eruptions: Stellar extinction period 1961-1978, J. Geophys. Res., 106, 2993-3003, 2001.

Thornes, J. E. and Constable, J.: John Constable's skies: A Fusion of Art and Science, Ed. Continuum, 288 pp., 1999.

Wild, M.: Enlightening Global Dimming and Brightening, B. Am. Meteorol. Soc., 93, 27-37, 2012.

Zerefos, C. S., Gerogiannis, V. T., Balis, D., Zerefos, S. C., and Kazantzidis, A.: Atmospheric effects of volcanic eruptions as seen by famous artists and depicted in their paintings, Atmos. Chem. Phys., 7, 4027-4042, doi:10.5194/acp-7-4027-2007, 2007.

Zielinski, G. A.: Stratospheric loading and optical depth estimates of explosive volcanism over the last 2100 years derived from the Greenland Ice Sheet Project 2 ice core, J. Geophys. Res., 100, 20937-20955, 1995.

Zielinski, G. A., Mayewski, P. A., Meeker, L. D., Whitlow, S., and Twickler, M. S.: A 110,000-yr record of explosive volcanism from the GISP2 (Greenland) ice core, Quaternary Res., 45, 109_ 188, 1996. 


\section{Appendix A}

Table A1. Paintings from the Tate Gallery analysed in this work.

\begin{tabular}{|c|c|c|}
\hline Image ID & Artist name & Title \\
\hline 1. D00670 & Turner, Joseph Mallord William & Windmill on Hill: Valley and Winding River in Middle Distance; Sunset Effect \\
\hline 2. D02474 & Turner, Joseph Mallord William & $\begin{array}{l}\text { Helmsley Sketchbook [Finberg LIII], Distant View of Whitby from the Moors: A } \\
\text { Windmill against a }\end{array}$ \\
\hline 3. D04118 & Turner, Joseph Mallord William & $\begin{array}{l}\text { Studies for Pictures Sketchbook [Finberg LXIX], Study for the Composition of } \\
\text { "Dolbadern Castle" }\end{array}$ \\
\hline 4. D04119 & Turner, Joseph Mallord William & $\begin{array}{l}\text { Studies for Pictures Sketchbook [Finberg LXIX], Study for the Composition of } \\
\text { "Dolbadern Castle", }\end{array}$ \\
\hline 5. D04127 & Turner, Joseph Mallord William & $\begin{array}{l}\text { Studies for Pictures Sketchbook [Finberg LXIX], Snowy Hills beside a Lake: } \\
\text { Evening Sky }\end{array}$ \\
\hline 6. D04128 & Turner, Joseph Mallord William & $\begin{array}{l}\text { Studies for Pictures Sketchbook [Finberg LXIX], Study for the Composition of } \\
\text { "Dolbadern Castle", }\end{array}$ \\
\hline 7. D08176 & Turner, Joseph Mallord William & Moonlight at Sea (The Needles) \\
\hline 8. D12502 & Turner, Joseph Mallord William & Skies Sketchbook [Finberg CLVIII], Red Sky and Crescent Moon \\
\hline 9. D16131 & Turner, Joseph Mallord William & $\begin{array}{l}\text { Naples: Rome. C. Studies Sketchbook [Finberg CLXXXVII], The Roman Cam- } \\
\text { pagna from Monte Testaccio }\end{array}$ \\
\hline 10. D16482 & Turner, Joseph Mallord William & $\begin{array}{l}\text { Small Roman Colour Studies Sketchbook [Finberg CXC], Moonlight over the Cam- } \\
\text { pagna }\end{array}$ \\
\hline 11. D20254 & Turner, Joseph Mallord William & Mayen in the Eifel \\
\hline 12. D22663 & Turner, Joseph Mallord William & Evening: A Windmill at Sunset \\
\hline 13. D22664 & Turner, Joseph Mallord William & Sunset across the Park from the Terrace of Petworth House \\
\hline 14. D22666 & Turner, Joseph Mallord William & Evening: A Boat on a River with a Distant Tower \\
\hline 15. D22674 & Turner, Joseph Mallord William & Sunset over the Ridge Seen from the North Pond in Petworth Park \\
\hline 16. D22716 & Turner, Joseph Mallord William & Setting Sun \\
\hline 17. D22719 & Turner, Joseph Mallord William & The Setting Sun over Petworth Park \\
\hline 18. D22767 & Turner, Joseph Mallord William & Petworth Park: Sunset ("Glade and Greensward") \\
\hline 19. D22768 & Turner, Joseph Mallord William & Sunset: A Boat on a River \\
\hline 20. D24635 & Turner, Joseph Mallord William & A Distant View of the Upperton Monument, from the Lake in Petworth Park \\
\hline 21. D24640 & Turner, Joseph Mallord William & Harbour Scene at Sunrise, possibly Margate \\
\hline 22. D24666 & Turner, Joseph Mallord William & The Scarlet Sunset \\
\hline 23. D24698 & Turner, Joseph Mallord William & Turner's Annual Tour: The Seine 1834 Watercolours, Le Havre: Sunset in the Port \\
\hline 24. D24757 & Turner, Joseph Mallord William & A View of Metz from the North \\
\hline 25. D25132 & Turner, Joseph Mallord William & Sunlight over Water \\
\hline 26. D25141 & Turner, Joseph Mallord William & Cilgerran Castle, Pembrokeshire \\
\hline 27. D25144 & Turner, Joseph Mallord William & The River: Sunset \\
\hline 28. D25201 & Turner, Joseph Mallord William & Looking out to Sea \\
\hline 29. D25233 & Turner, Joseph Mallord William & River with Trees: Sunset \\
\hline 30. D25246 & Turner, Joseph Mallord William & Castle Upnor, Kent: Preparatory Study \\
\hline 31. D25249 & Turner, Joseph Mallord William & River: Sunset \\
\hline 32. D25253 & Turner, Joseph Mallord William & Studies of Skies \\
\hline 33. D25258 & Turner, Joseph Mallord William & Evening \\
\hline 34. D25263 & Turner, Joseph Mallord William & The Line of Cliffs \\
\hline 35. D25300 & Turner, Joseph Mallord William & The Castle by the Sea \\
\hline 36. D25303 & Turner, Joseph Mallord William & River Scene: Sunset \\
\hline 37. D25315 & Turner, Joseph Mallord William & Sunset \\
\hline 38. D25329 & Turner, Joseph Mallord William & Sunset \\
\hline 39. D25330 & Turner, Joseph Mallord William & Fiery Sunset \\
\hline 40. D25331 & Turner, Joseph Mallord William & Crimson Sunset \\
\hline 41. D25332 & Turner, Joseph Mallord William & Sunset over Water \\
\hline 42. D25336 & Turner, Joseph Mallord William & A Ruin: Sunset \\
\hline 43. D25338 & Turner, Joseph Mallord William & Twilight over the Waters \\
\hline 44. D25361 & Turner, Joseph Mallord William & A Stormy Sunset \\
\hline 45. D25368 & Turner, Joseph Mallord William & $\begin{array}{l}\text { Sequels to the Liber Studiorum ("Little Liber") Watercolours, The Distant Tower: } \\
\text { Evening }\end{array}$ \\
\hline 46. D25403 & Turner, Joseph Mallord William & The Yellow Sky \\
\hline 47. D25412 & Turner, Joseph Mallord William & A Pink Sky above a Grey Sea \\
\hline 48. D25430 & Turner, Joseph Mallord William & Sequels to the Liber Studiorum ("Little Liber") Watercolours, Gloucester Cathedral \\
\hline 49. D25433 & Turner, Joseph Mallord William & Running Wave in a Cross-Tide: Evening \\
\hline
\end{tabular}


Table A1. Continued.

\begin{tabular}{|c|c|c|}
\hline Image ID & Artist Name & Title \\
\hline 50. D25443 & Turner, Joseph Mallord William & Barnstaple Bridge at Sunset \\
\hline 51. D25446 & Turner, Joseph Mallord William & Study for "The Golden Bough" \\
\hline 52. D25450 & Turner, Joseph Mallord William & Sunset \\
\hline 53. D25474 & Turner, Joseph Mallord William & Rochester Castle and Bridge \\
\hline 54. D25507 & Turner, Joseph Mallord William & Sunset over the Sea \\
\hline 55. D25514 & Turner, Joseph Mallord William & St Michael's Mount from Marazion, Cornwall \\
\hline 56. D27601 & Turner, Joseph Mallord William & Sunset over a City \\
\hline 57. D27689 & Turner, Joseph Mallord William & Rogers's Poems 1835 Watercolours, Tornaro (Rogers's “Poems") \\
\hline 58. D27716 & Turner, Joseph Mallord William & Rogers’s Poems 1835 Watercolours, Datur Hora Quieti \\
\hline 59. D28994 & Turner, Joseph Mallord William & Sunset over Lake or River \\
\hline 60. D29026 & Turner, Joseph Mallord William & Sunset \\
\hline 61. D32130 & Turner, Joseph Mallord William & $\begin{array}{l}\text { Roll Sketchbook of Venice [Finberg CCCXV], Venice: Sunset over Santa Maria } \\
\text { della Salute and the }\end{array}$ \\
\hline 62. D32152 & Turner, Joseph Mallord William & Venice: Sunset \\
\hline 63. D32185 & Turner, Joseph Mallord William & View of Town, with Yellow Sky \\
\hline 64. D32191 & Turner, Joseph Mallord William & Sunset on the Sea \\
\hline 65. D32203 & Turner, Joseph Mallord William & Orange Sunset \\
\hline 66. D33479 & Turner, Joseph Mallord William & $\begin{array}{l}\text { Fribourg, Lausanne and Geneva Sketchbook [Finberg CCCXXXII], Geneva, the } \\
\text { Jura Mountains and }\end{array}$ \\
\hline 67. D33484 & Turner, Joseph Mallord William & $\begin{array}{l}\text { Fribourg, Lausanne and Geneva Sketchbook [Finberg CCCXXXII], Sunset on a } \\
\text { Lake }\end{array}$ \\
\hline 68. D33501 & Turner, Joseph Mallord William & $\begin{array}{l}\text { Fribourg, Lausanne and Geneva Sketchbook [Finberg CCCXXXII], Sunset, Lake } \\
\text { of Lucerne }\end{array}$ \\
\hline 69. D33504 & Turner, Joseph Mallord William & $\begin{array}{l}\text { Fribourg, Lausanne and Geneva Sketchbook [Finberg CCCXXXII], Mont Pilatus: } \\
\text { Sunset }\end{array}$ \\
\hline 70. D35260 & Turner, Joseph Mallord William & The Whalers Sketchbook [Finberg CCCLIII], Sea Monsters and Vessels at Sunset \\
\hline 71. D35378 & Turner, Joseph Mallord William & Ideas of Folkestone Sketchbook [Finberg CCCLVI], Sunset, over the Water \\
\hline 72. D35392 & Turner, Joseph Mallord William & $\begin{array}{l}\text { Ambleteuse and Wimereux Sketchbook [Finberg CCCLVII], Yellow Sun over } \\
\text { Water }\end{array}$ \\
\hline 73. D35394 & Turner, Joseph Mallord William & Ambleteuse and Wimereux Sketchbook [Finberg CCCLVII], Sunset at Ambleteuse \\
\hline 74. D35927 & Turner, Joseph Mallord William & A Lurid Sunset \\
\hline 75. D35943 & Turner, Joseph Mallord William & Sunset over Yellow-Green Waters \\
\hline 76. D35950 & Turner, Joseph Mallord William & Yellow Sunset \\
\hline 77. D35973 & Turner, Joseph Mallord William & The Bass Rock \\
\hline 78. D35986 & Turner, Joseph Mallord William & Sunset: Study for "Flint Castle, on the Welsh Coast" \\
\hline 79. D36060 & Turner, Joseph Mallord William & The Rigi \\
\hline 80. D36078 & Turner, Joseph Mallord William & Sunset. (Sunrise) \\
\hline 81. D36123 & Turner, Joseph Mallord William & The Red Rigi: Sample Study \\
\hline 82. D36149 & Turner, Joseph Mallord William & Sunset, with Smoke from a Distant Steamer \\
\hline 83. D36153 & Turner, Joseph Mallord William & Distant View of Regensburg from the Dreifaltigkeitsberg \\
\hline 84. D36159 & Turner, Joseph Mallord William & Sunset: A Fish Market on the Beach \\
\hline 85. D36174 & Turner, Joseph Mallord William & The Walhalla, near Regensburg on the Danube \\
\hline 86. D36211 & Turner, Joseph Mallord William & Lausanne: Sunset \\
\hline 87. D36242 & Turner, Joseph Mallord William & Geneva \\
\hline 88. D36293 & Turner, Joseph Mallord William & Yellow and Blue Sunset over Water \\
\hline 89. D36679 & Turner, Joseph Mallord William & Sunset Seen from a Beach with Breakwater \\
\hline 90. N00304 & Wilson, Richard & Lake Avernus and the Island of Capri \\
\hline 91. N00309 & Gainsborough, Thomas & Boy Driving Cows near a Pool \\
\hline 92. N00342 & Callcott, Sir Augustus Wall & Dutch Landscape with Cattle \\
\hline 93. N00499 & Turner, Joseph Mallord William & The Decline of the Carthaginian Empire ... \\
\hline 94. N00519 & Turner, Joseph Mallord William & Regulus \\
\hline 95. N00559 & Turner, Joseph Mallord William & Petworth Park: Tillington Church in the Distance \\
\hline 96. N00560 & Turner, Joseph Mallord William & Chichester Canal \\
\hline 97. N00886 & Reynolds, Sir Joshua & Admiral Viscount Keppel \\
\hline 98. N00926 & Crome, John & A Windmill near Norwich \\
\hline 99. N01290 & Wilson, Richard & Landscape with Bathers, Cattle and Ruin \\
\hline 100. N01656 & McLachlan, Thomas Hope & Evening Quiet \\
\hline
\end{tabular}


Table A1. Continued.

\begin{tabular}{|c|c|c|}
\hline Image ID & Artist name & Title \\
\hline 101. N01876 & Turner, Joseph Mallord William & Sunset \\
\hline 102. N01902 & Brett, John & The British Channel Seen from the Dorsetshire Cliffs \\
\hline 103. N02064 & Turner, Joseph Mallord William & The Chain Pier, Brighton \\
\hline 104. N02065 & Turner, Joseph Mallord William & A Ship Aground \\
\hline 105. N02066 & Turner, Joseph Mallord William & The Arch of Constantine, Rome \\
\hline 106. N02067 & Turner, Joseph Mallord William & Tivoli: Tobias and the Angel \\
\hline 107. N02645 & Crome, John & Moonrise on the Yare (?) \\
\hline 108. N02647 & Wilson, Richard & River View, on the Arno (?) \\
\hline 109. N02701 & Turner, Joseph Mallord William & The Lake, Petworth, Sunset \\
\hline 110. N02990 & Turner, Joseph Mallord William & Ariccia (?): Sunset \\
\hline 111. N03026 & Turner, Joseph Mallord William & Classical Harbour Scene \\
\hline 112. N03382 & Turner, Joseph Mallord William & Claudian Harbour Scene \\
\hline 113. N04665 & Turner, Joseph Mallord William & Sun Setting over a Lake \\
\hline 114. N04937 & Ward, James & L'Amour de Cheval \\
\hline 115. N05361 & Crome, John & Yarmouth Harbour - Evening \\
\hline 116. N05486 & Turner, Joseph Mallord William & Sunset From the Top of the Rigi \\
\hline 117. N05530 & Turner, Joseph Mallord William & Seacoast with Ruin, probably the Bay of Baiae \\
\hline 118. N05853 & Boitard, Louis Philippe & An Exact Representation of the Game of Cricket \\
\hline 119. T00921 & De Loutherbourg, Philip James & Travellers Attacked by Banditti \\
\hline 120. T03163 & Garstin, Norman & Haycocks and Sun \\
\hline 121. T03543 & Anderton, Henry & Mountain Landscape with Dancing Shepherd \\
\hline 122. T03883 & Turner, Joseph Mallord William & The Lake, Petworth: Sunset, Fighting Bucks \\
\hline 123. T03884 & Turner, Joseph Mallord William & The Lake, Petworth: Sunset, a Stag Drinking \\
\hline 124. T03885 & Turner, Joseph Mallord William & Chichester Canal \\
\hline
\end{tabular}




\section{Appendix B}

Table B1. Volcanic eruptions in 1500-2000 with volcanic explosivity index (VEI) of 4 or more.

\begin{tabular}{|c|c|c|c|c|}
\hline No. & Year & Volcano & VEI* & Reference \\
\hline 1 & 1522 & ? Arenal, Costa Rica (C-14: 1525) & 4 & [1] \\
\hline 2 & 1568 & ? Billy Mitchell (C-14: 1580) & 6 & [1] \\
\hline 3 & 1586 & Kelut, Java & $5 ?$ & [1] \\
\hline 4 & 1595 & Raung, Java & $5 ?$ & [1] \\
\hline 5 & & Ruiz, Colombia & 4 & [1] \\
\hline 6 & 1600 & Huynaputina, Peru & $6 ?$ & [1] \\
\hline 7 & $? * 1605$ & Momotombo, Nicaragua & 4 & [1] \\
\hline 8 & 1622 & ? Colima, Mexico & 4 & [1] \\
\hline 9 & C-14: 1630 & Raoul Island, Kermadec & 4 & [1] \\
\hline 10 & 1641 & Parker, Indonesia & 6 & [1] \\
\hline 11 & 1660 & ? Teon, Banda & $4 ?$ & [1] \\
\hline 12 & & ? Guagua Pichinchia, Ecuador & 4 & [1] \\
\hline 13 & 1665 & ? Long Island, New Guinea (C-14: 1660) & $6 ?$ & [1] \\
\hline 14 & 1674 & Gamkonora, Indonesia & $5 ?$ & [1] \\
\hline 15 & 1680 & Tongkoko, Sulawesi & $5 ?$ & [1] \\
\hline 16 & 1693 & Serua, Banda & $4 ?$ & [1] \\
\hline 17 & $? 1721$ & Raoul Island, Kermadec (C-14: 1720) & 4 & [1] \\
\hline 18 & & Cerro Bravo, Colombia (T) & 4 & [1] \\
\hline 19 & $? 1737$ & Fuego, Guatemala & $4 ?$ & [1] \\
\hline 20 & 1744 & Cotopaxi, Equador & 4 & [1] \\
\hline 21 & 1760 & Michoacan, Mexico & 4 & [1] \\
\hline 22 & & Makian, Indonesia & $4 ?$ & [1] \\
\hline 23 & 1783 & Lakagigar, Iceland & 4 & [2] \\
\hline 24 & 1794 & ? San Martin, Mexico & $4 ?$ & [1] \\
\hline 25 & $? 1808$ & Unknown & $?$ & [1] \\
\hline 26 & 1813 & Soufriere St. Vincent, W-Indies & 4 & [1] \\
\hline 27 & & Awu, Indonesia & $4 ?$ & [1] \\
\hline 28 & & Suwanose-Jima, Japan & 4 & {$[1]$} \\
\hline 29 & 1815 & Tambora, Indonesia & 7 & {$[1,2]$} \\
\hline 30 & 1823 & Galunggung, Java & 5 & {$[1]$} \\
\hline 31 & 1831 & Babuyan Claro, Philippines & $4 ?$ & {$[1]$} \\
\hline 32 & 1835 & Coseguina, Nicaragua & 5 & {$[1,2]$} \\
\hline 33 & 1861 & Makian, Indonesia & $4 ?$ & [1] \\
\hline 34 & 1875 & Askja, Iceland & 5 & [2] \\
\hline 35 & 1880 & Fuego, Guatemala & $4 ?$ & {$[1]$} \\
\hline 36 & 1883 & Krakatau, Indonesia & 6 & {$[1,2]$} \\
\hline 37 & 1886 & Tarawera, New Zealand & 5 & {$[2]$} \\
\hline 38 & 1890 & Colima, Mexico & 4 & [1] \\
\hline 39 & 1902 & Pelee, W-Indies & 4 & [1] \\
\hline 40 & & Soufriere St. Vincent, W-Indies & 4 & {$[1]$} \\
\hline 41 & 1903 & Santa Maria, Guatemala & 6 & {$[1,2]$} \\
\hline 42 & 1907 & Ksudach, Kamchatka, Russia & 5 & {$[2]$} \\
\hline 43 & $? 1911$ & Lolobau, SW-Pacific & 4 & {$[1]$} \\
\hline 44 & & Taal, Philippines & 4 & [1] \\
\hline 45 & 1912 & Katmai, Alaska & 6 & [2] \\
\hline 46 & 1953 & Ambrym, Vanuatu & $4+$ & [1] \\
\hline 47 & & Lamington, New Guinea & 4 & [1] \\
\hline 48 & & Bagana, SW-Pacific & 4 & [1] \\
\hline 49 & 1963 & Agung, Indonesia & 4 & {$[1,2]$} \\
\hline 50 & 1968 & Fernandina, Galapagos & 4 & {$[1]$} \\
\hline 51 & 1974 & Fuego, Guatemala & 4 & {$[1]$} \\
\hline 52 & 1980 & St. Helens, United States & 5 & {$[2]$} \\
\hline 53 & 1982 & El Chichon, Mexico & 5 & {$[1,2]$} \\
\hline 54 & 1991 & Pinatubo, Philippines & 6 & {$[1,2]$} \\
\hline
\end{tabular}

[1]: after Ammann and Naveau (2003) at

ftp://ftp.ncdc.noaa.gov/pub/data/paleo/climate forcing/volcanic aerosols/ammann2003 eruptions.pdf. [2]: Robock (2000)

* It should be mentioned that VEI is not a good index of stratospheric sulfate loading, since it measures the explosivity of an eruption and not its stratospheric injection. 


\section{Appendix C}

R/ G ratios with and without structural differences after Tambora (1815) and Krakatau (1883)

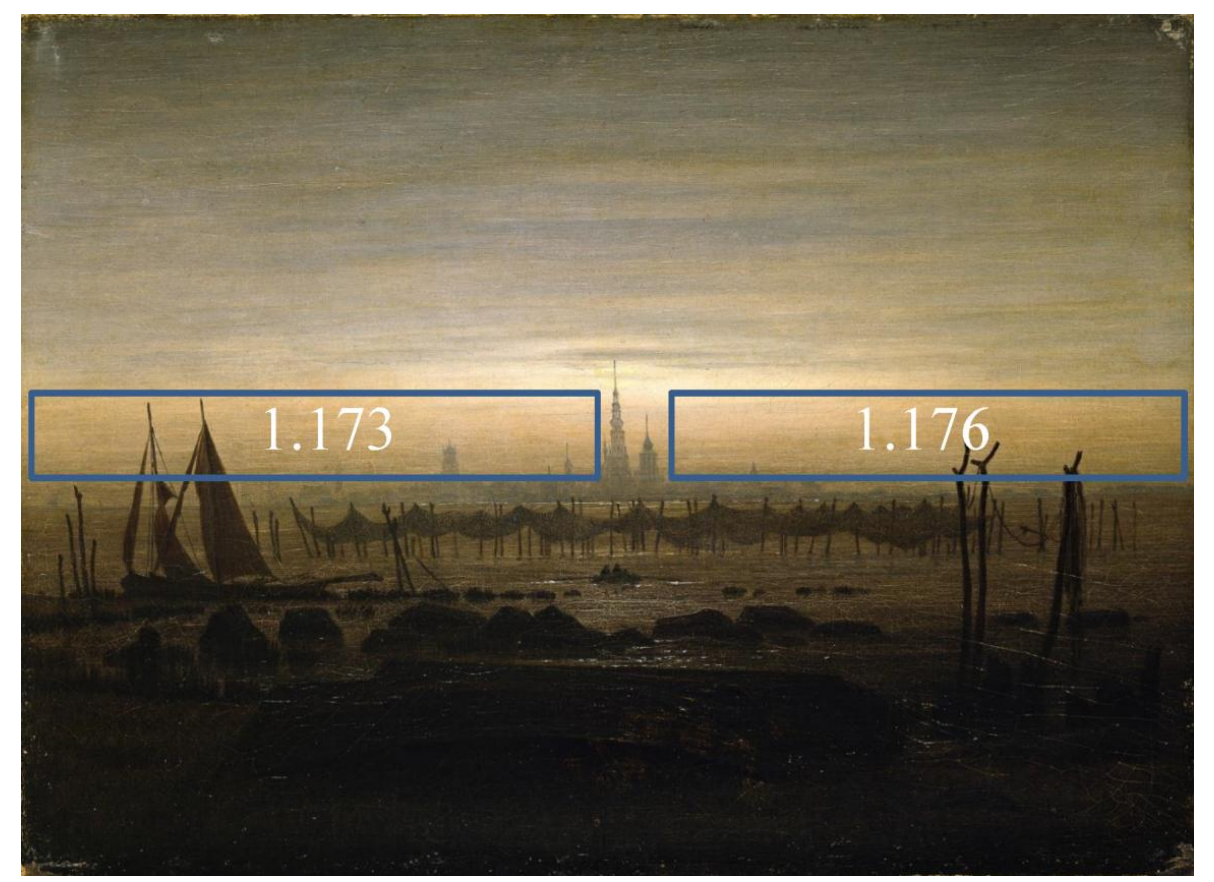

Fig. C1. Caspar David Friedrich, Griefswald in the Moonlight, 1817. Corresponding R/G ratios were averaged inside each box. 


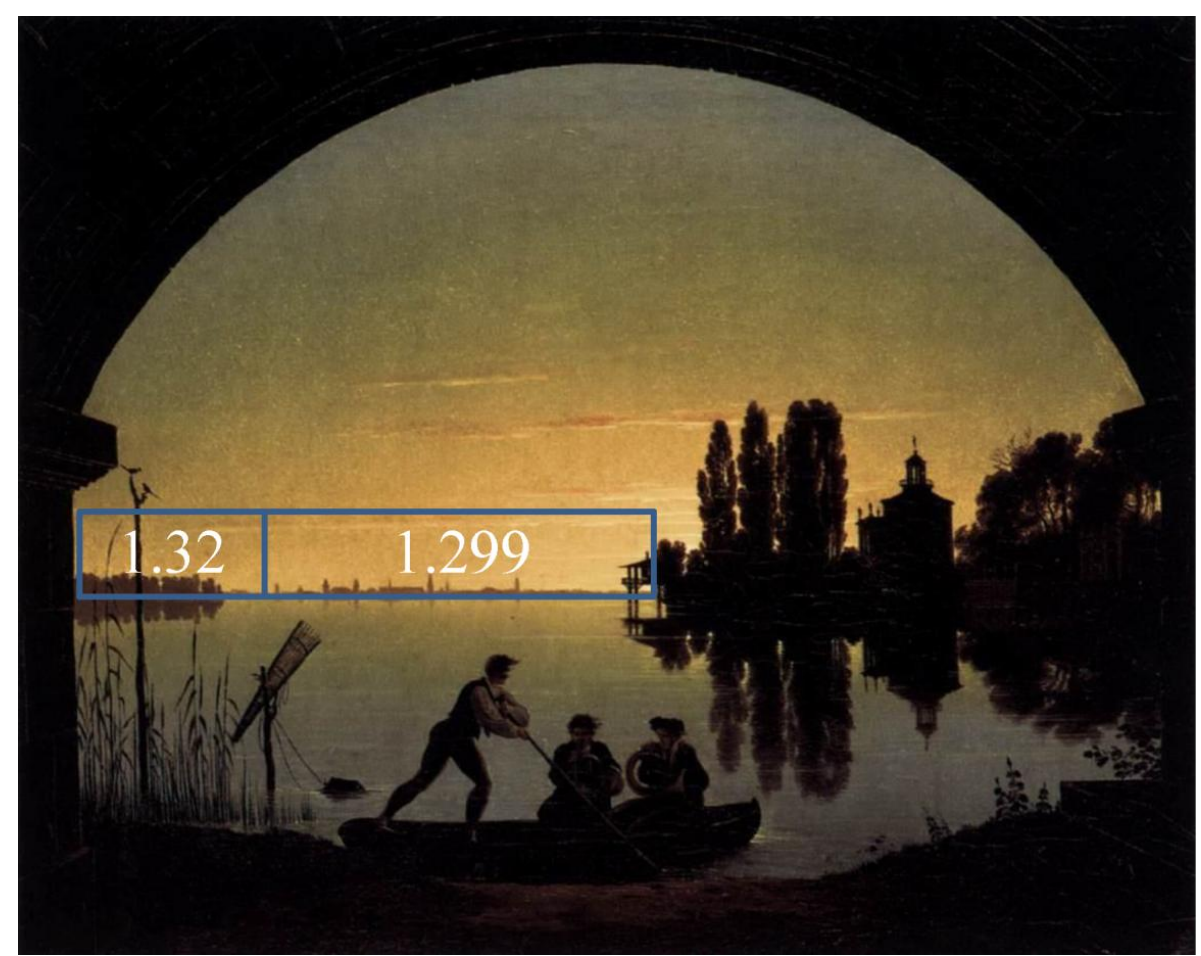

Fig. C2. Karl Friedrich Schinkel, The Banks of the Spree near Stralau, 1817. Corresponding R/G ratios were averaged inside each box.

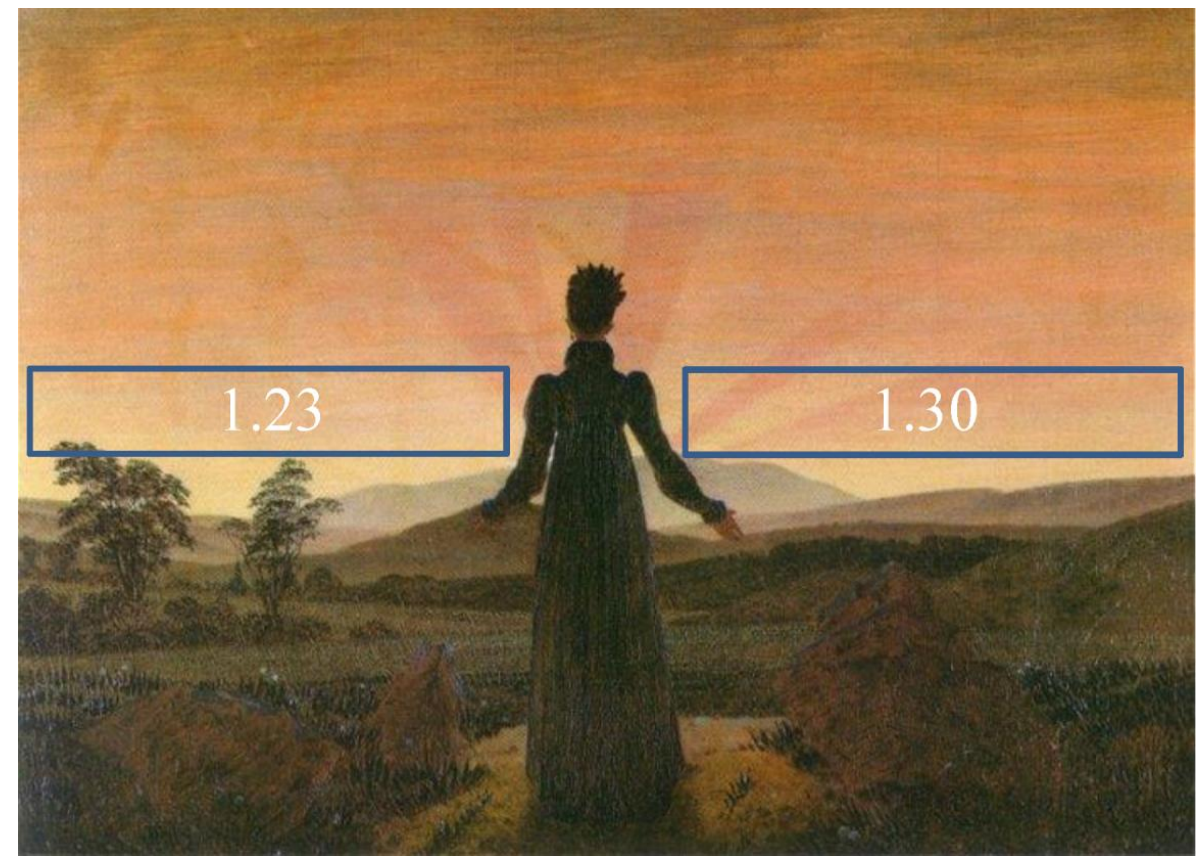

Fig. C3. Caspar David Friedrich, Woman in front of the Setting Sun, 1818. Corresponding R/G ratios were averaged inside each box. 


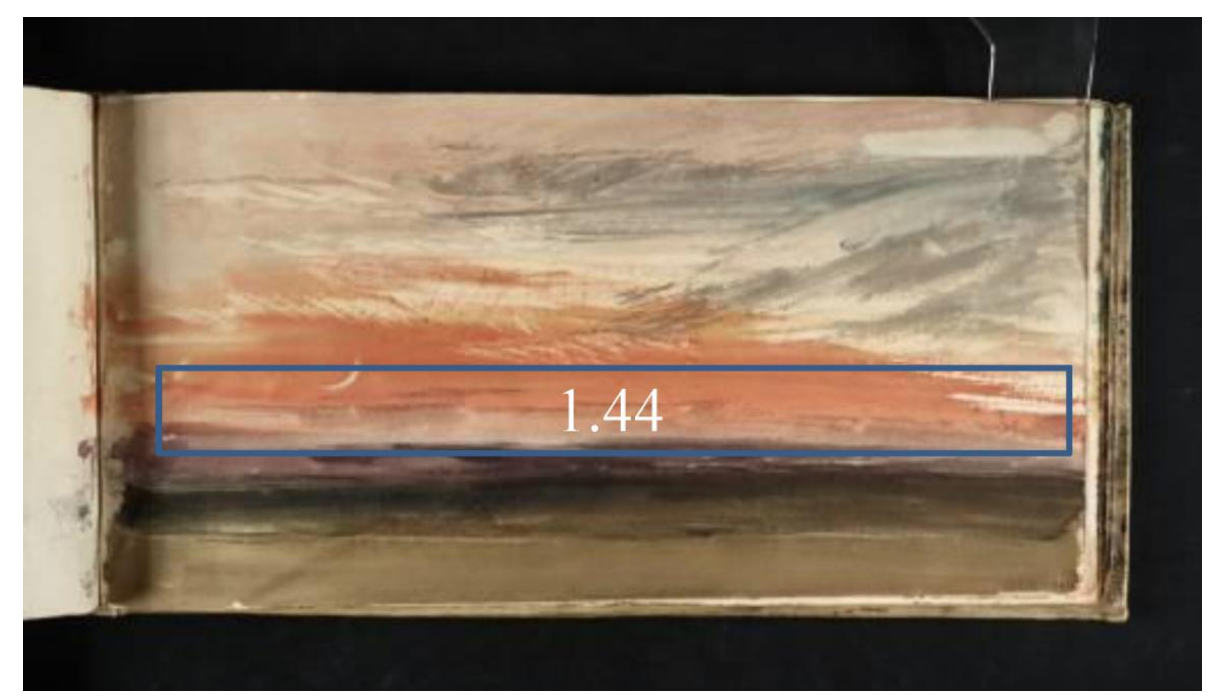

Fig. C4. Joseph Mallord William Turner, Red sky and crescent moon, c. 1818. Corresponding R/G ratios were averaged inside the box.

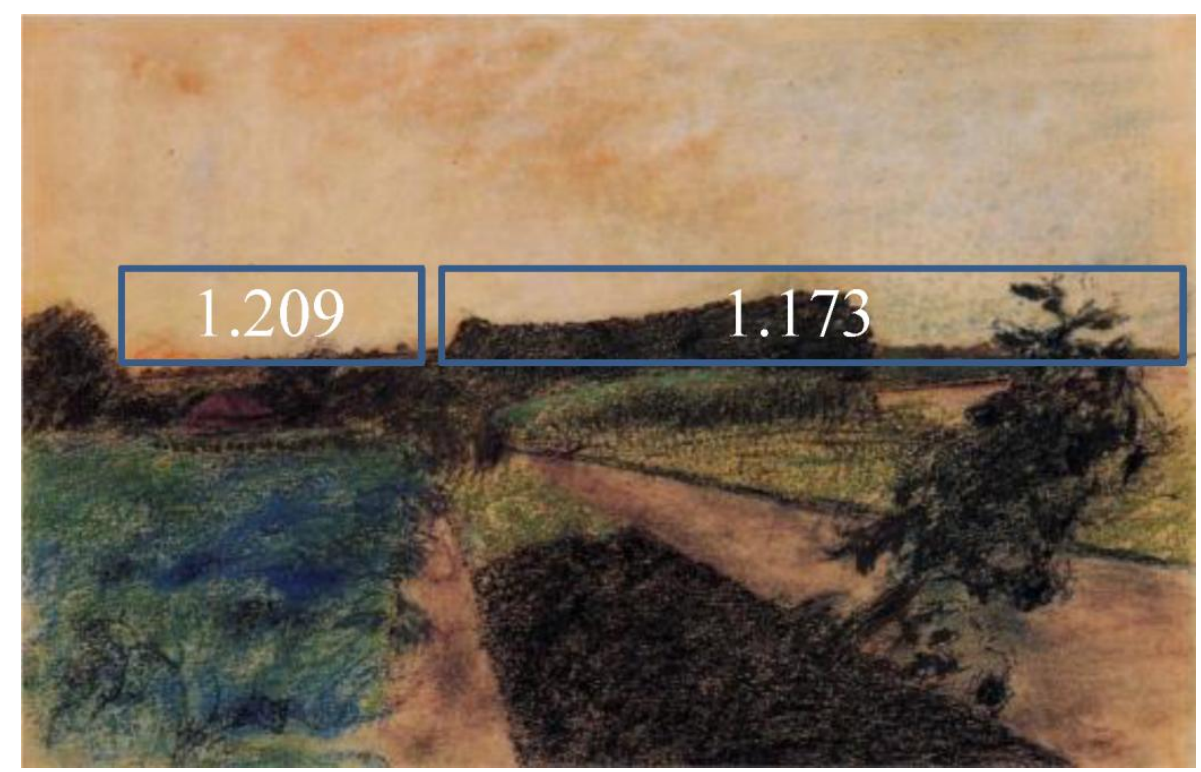

Fig. C5. Edgar Degas, Landscape on the Orne, c. 1884. Corresponding R/G ratios were averaged inside each box. 


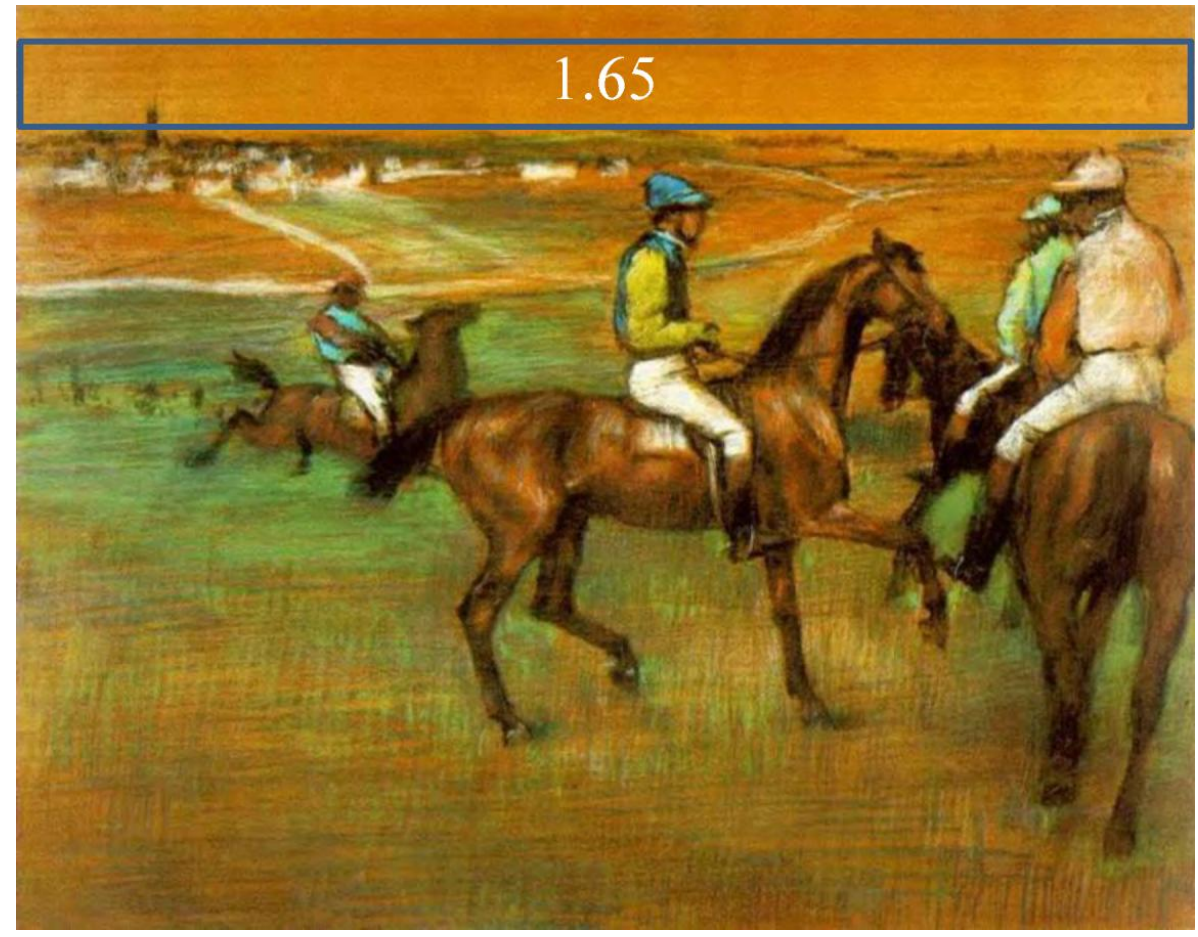

Fig. C6. Edgar Degas, Race Horses, 1885. Corresponding R/G ratios were averaged inside the box. 
Appendix D

Table D1. Volcanic aerosol indices and AOD proxies shown in Fig. 4.

\begin{tabular}{|c|c|c|c|c|c|c|c|}
\hline \multirow[t]{2}{*}{ Year } & N.H. DVI & $\begin{array}{l}\text { N.H. AOD } \\
\text { from paintings }\end{array}$ & AOD & AOD & AOD & AOD & $\begin{array}{c}\text { Sulfate } \\
\text { aerosols (Tg) }\end{array}$ \\
\hline & $\begin{array}{c}\text { (Lamb, 1970, } \\
\text { 1977, 1983) }\end{array}$ & $\begin{array}{l}\text { (this } \\
\text { study) }\end{array}$ & $\begin{array}{l}\text { (Robertson } \\
\text { et al., 2001) }\end{array}$ & $\begin{array}{c}\text { Crowley and } \\
\text { Unterman (2013) }\end{array}$ & $\begin{array}{c}\text { (Sato et } \\
\text { al., 1993) }\end{array}$ & $\begin{array}{l}\text { (Stothers, } \\
1996,2001)\end{array}$ & $\begin{array}{l}\text { (Gao et } \\
\text { al., 2008) }\end{array}$ \\
\hline 1500 & 200 & - & 0.0010 & - & - & - & - \\
\hline 1501 & 150 & 0.103 & 0.0117 & - & - & - & - \\
\hline 1502 & 100 & - & 0.0110 & - & - & - & - \\
\hline 1503 & 50 & 0.12 & 0.0110 & 0.01 & - & - & 1.72 \\
\hline 1504 & - & - & 0.0002 & 0.003 & - & - & - \\
\hline 1505 & - & - & 0.0076 & 0.008 & - & - & - \\
\hline 1506 & - & - & - & 0.008 & - & - & - \\
\hline 1507 & - & - & - & 0.002 & - & - & - \\
\hline 1508 & - & - & - & 0.021 & - & - & - \\
\hline 1509 & - & - & 0.0055 & 0.012 & - & - & - \\
\hline 1510 & - & - & 0.0022 & 0.003 & - & - & - \\
\hline 1511 & - & - & 0.0076 & 0.001 & - & - & - \\
\hline 1512 & - & - & - & - & - & - & 4.24 \\
\hline 1513 & - & - & 0.0112 & - & - & - & - \\
\hline 1514 & - & - & 0.0008 & - & - & - & - \\
\hline 1515 & - & - & 0.0037 & 0.016 & - & - & - \\
\hline 1516 & - & - & 0.0000 & 0.005 & - & - & - \\
\hline 1517 & - & - & 0.0010 & 0.001 & - & - & - \\
\hline 1518 & - & - & 0.0007 & - & - & - & - \\
\hline 1519 & - & - & 0.0007 & - & - & - & - \\
\hline 1520 & - & - & - & 0.004 & - & - & - \\
\hline 1521 & - & - & 0.0039 & 0.008 & - & - & - \\
\hline 1522 & - & - & 0.0013 & 0.002 & - & - & - \\
\hline 1523 & - & - & 0.0031 & 0.004 & - & - & - \\
\hline 1524 & - & - & 0.0035 & 0.008 & - & - & - \\
\hline 1525 & - & - & 0.0023 & 0.009 & - & - & - \\
\hline 1526 & - & - & 0.0010 & 0.025 & - & - & 3.54 \\
\hline 1527 & - & - & 0.0079 & 0.006 & - & - & - \\
\hline 1528 & - & - & - & 0.003 & - & - & - \\
\hline 1529 & - & - & 0.0068 & - & - & - & - \\
\hline 1530 & - & - & 0.0026 & 0.003 & - & - & - \\
\hline 1531 & - & - & 0.0025 & 0.001 & - & - & - \\
\hline 1532 & - & - & 0.0007 & - & - & - & - \\
\hline 1533 & - & - & 0.0041 & 0.002 & - & - & - \\
\hline 1534 & - & - & 0.0002 & - & - & - & 3.86 \\
\hline 1535 & 50 & - & - & - & - & - & - \\
\hline 1536 & 50 & - & 0.0009 & 0.007 & - & - & - \\
\hline 1537 & 50 & - & 0.0052 & 0.014 & - & - & - \\
\hline 1538 & - & - & 0.0045 & 0.003 & - & - & - \\
\hline 1539 & - & - & 0.0037 & 0.001 & - & - & - \\
\hline 1540 & - & - & 0.0095 & - & - & - & - \\
\hline 1541 & - & - & 0.0066 & - & - & - & - \\
\hline 1542 & - & - & 0.0029 & 0.011 & - & - & - \\
\hline 1543 & - & - & 0.0087 & 0.004 & - & - & - \\
\hline 1544 & - & - & 0.0021 & 0.001 & - & - & - \\
\hline 1545 & - & - & - & - & - & - & - \\
\hline 1546 & - & - & 0.0023 & - & - & - & - \\
\hline 1547 & - & - & - & - & - & - & - \\
\hline
\end{tabular}


Table D1. Continued.

\begin{tabular}{|c|c|c|c|c|c|c|c|}
\hline \multirow[t]{2}{*}{ Year } & N.H. DVI & $\begin{array}{c}\text { N.H. AOD } \\
\text { from paintings }\end{array}$ & AOD & AOD & AOD & AOD & $\begin{array}{c}\text { Sulfate } \\
\text { aerosols (Tg) }\end{array}$ \\
\hline & $\begin{array}{c}\text { (Lamb, 1970, } \\
1977,1983)\end{array}$ & $\begin{array}{l}\text { (this } \\
\text { study) }\end{array}$ & $\begin{array}{l}\text { (Robertson } \\
\text { et al., 2001) }\end{array}$ & $\begin{array}{c}\text { Crowley and } \\
\text { Unterman (2013) }\end{array}$ & $\begin{array}{l}\text { (Sato et } \\
\text { al., 1993) }\end{array}$ & $\begin{array}{c}\text { (Stothers, } \\
1996,2001 \text { ) }\end{array}$ & $\begin{array}{l}\text { (Gao et } \\
\text { al., 2008) }\end{array}$ \\
\hline 1548 & - & - & - & - & - & - & - \\
\hline 1549 & - & - & 0.0020 & - & - & - & - \\
\hline 1550 & - & - & 0.0086 & - & - & - & - \\
\hline 1551 & - & - & 0.0016 & - & - & - & - \\
\hline 1552 & - & - & 0.0030 & - & - & - & - \\
\hline 1553 & 100 & - & 0.0018 & 0.012 & - & - & - \\
\hline 1554 & 500 & - & 0.0020 & 0.028 & - & - & - \\
\hline 1555 & 350 & - & 0.0121 & 0.012 & - & - & - \\
\hline 1556 & 200 & - & 0.0028 & 0.003 & - & - & - \\
\hline 1557 & 100 & 0.168 & - & - & - & - & - \\
\hline 1558 & - & - & 0.0007 & - & - & - & - \\
\hline 1559 & - & - & 0.0018 & - & - & - & - \\
\hline 1560 & - & - & 0.0006 & - & - & - & - \\
\hline 1561 & - & - & 0.0003 & 0.03 & - & - & - \\
\hline 1562 & - & - & 0.0037 & 0.01 & - & - & - \\
\hline 1563 & - & - & 0.0028 & 0.019 & - & - & - \\
\hline 1564 & - & - & 0.0039 & 0.006 & - & - & - \\
\hline 1565 & - & - & 0.0168 & 0.001 & - & - & - \\
\hline 1566 & - & - & 0.0011 & - & - & - & - \\
\hline 1567 & - & - & 0.0004 & 0.012 & - & - & - \\
\hline 1568 & - & - & 0.0033 & 0.007 & - & - & - \\
\hline 1569 & - & - & 0.0007 & 0.002 & - & - & - \\
\hline 1570 & - & - & 0.0041 & 0.011 & - & - & - \\
\hline 1571 & - & - & 0.0151 & 0.015 & - & - & - \\
\hline 1572 & - & - & - & 0.009 & - & - & - \\
\hline 1573 & - & - & 0.0003 & 0.015 & - & - & - \\
\hline 1574 & - & - & 0.0024 & 0.003 & - & - & - \\
\hline 1575 & - & - & 0.0092 & 0.023 & - & - & - \\
\hline 1576 & - & - & 0.0335 & 0.053 & - & - & - \\
\hline 1577 & - & - & 0.0917 & 0.019 & - & - & - \\
\hline 1578 & - & - & 0.0067 & 0.02 & - & - & - \\
\hline 1579 & - & - & 0.0064 & 0.007 & - & - & - \\
\hline 1580 & - & - & 0.0071 & 0.012 & - & - & - \\
\hline 1581 & - & - & 0.0052 & 0.003 & - & - & - \\
\hline 1582 & - & - & 0.0003 & 0.001 & - & - & - \\
\hline 1583 & - & - & - & 0.011 & - & - & - \\
\hline 1584 & - & - & 0.0068 & 0.003 & - & - & 24.23 \\
\hline 1585 & - & - & 0.0018 & 0.053 & - & - & - \\
\hline 1586 & 200 & - & 0.0868 & 0.018 & - & - & - \\
\hline 1587 & 150 & - & 0.0639 & 0.004 & - & - & - \\
\hline 1588 & 100 & - & 0.0143 & 0.015 & - & - & - \\
\hline 1589 & 50 & - & 0.0059 & 0.005 & - & - & - \\
\hline 1590 & - & - & 0.0029 & 0.001 & - & - & - \\
\hline 1591 & - & - & - & 0.01 & - & - & - \\
\hline 1592 & - & - & - & 0.003 & - & - & - \\
\hline 1593 & 200 & - & 0.0421 & 0.019 & - & - & 9.54 \\
\hline 1594 & 150 & - & 0.0620 & 0.068 & - & - & - \\
\hline 1595 & 100 & - & 0.0101 & 0.028 & - & - & - \\
\hline 1596 & 50 & - & 0.0010 & 0.021 & - & - & - \\
\hline 1597 & 40 & - & 0.0008 & 0.007 & - & - & - \\
\hline 1598 & 30 & - & 0.0016 & 0.001 & - & - & - \\
\hline 1599 & 20 & - & 0.0147 & - & - & - & - \\
\hline
\end{tabular}


Table D1. Continued.

\begin{tabular}{|c|c|c|c|c|c|c|c|}
\hline \multirow[t]{2}{*}{ Year } & N.H. DVI & $\begin{array}{c}\text { N.H. AOD } \\
\text { from paintings }\end{array}$ & AOD & AOD & AOD & AOD & $\begin{array}{c}\text { Sulfate } \\
\text { aerosols }(\mathrm{Tg})\end{array}$ \\
\hline & $\begin{array}{c}\text { (Lamb, 1970, } \\
1977,1983)\end{array}$ & $\begin{array}{l}\text { (this } \\
\text { study) }\end{array}$ & $\begin{array}{l}\text { (Robertson } \\
\text { et al., 2001) }\end{array}$ & $\begin{array}{c}\text { Crowley and } \\
\text { Unterman (2013) }\end{array}$ & $\begin{array}{c}\text { (Sato et } \\
\text { al., 1993) }\end{array}$ & $\begin{array}{c}\text { (Stothers, } \\
1996,2001)\end{array}$ & $\begin{array}{c}\text { (Gao et } \\
\text { al., 2008) }\end{array}$ \\
\hline 1600 & 10 & 0.084 & 0.0729 & 0.147 & - & - & 56.59 \\
\hline 1601 & 400 & - & 0.0994 & 0.132 & - & - & - \\
\hline 1602 & 300 & - & 0.0065 & 0.05 & - & - & - \\
\hline 1603 & 210 & - & 0.0064 & 0.019 & - & - & - \\
\hline 1604 & 110 & - & 0.0062 & 0.007 & - & - & - \\
\hline 1605 & 10 & - & 0.0049 & - & - & - & - \\
\hline 1606 & 20 & - & 0.0007 & - & - & - & - \\
\hline 1607 & 50 & 0.112 & 0.0017 & 0.013 & - & - & - \\
\hline 1608 & 50 & - & 0.0011 & 0.004 & - & - & - \\
\hline 1609 & 50 & - & 0.0014 & 0.001 & - & - & - \\
\hline 1610 & 40 & 0.097 & 0.0005 & 0.006 & - & - & - \\
\hline 1611 & 30 & - & - & 0.002 & - & - & - \\
\hline 1612 & 20 & 0.101 & 0.0018 & - & - & - & - \\
\hline 1613 & 10 & - & 0.0059 & 0.005 & - & - & - \\
\hline 1614 & 200 & - & 0.0010 & 0.014 & - & - & - \\
\hline 1615 & 150 & - & - & 0.004 & - & - & - \\
\hline 1616 & 100 & - & - & 0.001 & - & - & - \\
\hline 1617 & 50 & - & 0.0003 & - & - & - & - \\
\hline 1618 & - & - & 0.0072 & - & - & - & - \\
\hline 1619 & - & - & 0.0209 & - & - & - & 5.23 \\
\hline 1620 & - & - & 0.0042 & - & - & - & - \\
\hline 1621 & - & - & 0.0017 & 0.025 & - & - & - \\
\hline 1622 & - & - & 0.0102 & 0.033 & - & - & - \\
\hline 1623 & - & - & 0.0017 & 0.007 & - & - & - \\
\hline 1624 & - & - & 0.0056 & 0.002 & - & - & - \\
\hline 1625 & 100 & 0.13 & 0.0069 & - & - & - & - \\
\hline 1626 & 75 & - & - & 0.004 & - & - & - \\
\hline 1627 & 50 & 0.115 & 0.0005 & 0.001 & - & - & - \\
\hline 1628 & 25 & - & 0.0006 & - & - & - & - \\
\hline 1629 & - & - & 0.0076 & - & - & - & - \\
\hline 1630 & - & - & 0.0022 & 0.01 & - & - & - \\
\hline 1631 & 120 & - & - & 0.003 & - & - & - \\
\hline 1632 & 90 & - & 0.0022 & 0.001 & - & - & - \\
\hline 1633 & 60 & - & 0.0010 & - & - & - & - \\
\hline 1634 & 30 & - & 0.0030 & - & - & - & - \\
\hline 1635 & - & - & 0.0053 & - & - & - & - \\
\hline 1636 & 40 & 0.102 & 0.0048 & - & - & - & - \\
\hline 1637 & 30 & 0.067 & 0.0014 & - & - & - & - \\
\hline 1638 & 120 & 0.151 & 0.0004 & - & - & - & - \\
\hline 1639 & 85 & - & - & - & - & - & - \\
\hline 1640 & 150 & 0.284 & 0.0462 & 0.022 & - & - & - \\
\hline 1641 & 400 & - & 0.0705 & 0.157 & - & - & 51.6 \\
\hline 1642 & 275 & 0.35 & 0.0355 & 0.101 & - & - & - \\
\hline 1643 & 175 & 0.125 & 0.0019 & 0.036 & - & - & - \\
\hline 1644 & 75 & - & - & 0.013 & - & - & - \\
\hline 1645 & - & - & 0.0036 & 0.027 & - & - & - \\
\hline 1646 & 60 & - & 0.0089 & 0.007 & - & - & - \\
\hline 1647 & 45 & - & - & 0.002 & - & - & - \\
\hline 1648 & 30 & 0.097 & 0.0021 & - & - & - & - \\
\hline 1649 & 15 & 0.08 & - & - & - & - & - \\
\hline 1650 & 100 & 0.251 & 0.0017 & - & - & - & - \\
\hline 1651 & 75 & - & 0.0015 & - & - & - & - \\
\hline 1652 & 50 & 0.104 & 0.0010 & - & - & - & - \\
\hline
\end{tabular}


Table D1. Continued.

\begin{tabular}{|c|c|c|c|c|c|c|c|}
\hline \multirow[t]{2}{*}{ Year } & N.H. DVI & $\begin{array}{c}\text { N.H. AOD } \\
\text { from paintings }\end{array}$ & AOD & AOD & AOD & AOD & $\begin{array}{c}\text { Sulfate } \\
\text { aerosols }(\mathrm{Tg})\end{array}$ \\
\hline & $\begin{array}{c}(\mathrm{Lamb}, 1970, \\
1977,1983)\end{array}$ & $\begin{array}{l}\text { (this } \\
\text { study) }\end{array}$ & $\begin{array}{l}\text { (Robertson } \\
\text { et al., 2001) }\end{array}$ & $\begin{array}{c}\text { Crowley and } \\
\text { Unterman (2013) }\end{array}$ & $\begin{array}{c}\text { (Sato et } \\
\text { al., 1993) }\end{array}$ & $\begin{array}{c}\text { (Stothers, } \\
1996,2001)\end{array}$ & $\begin{array}{c}\text { (Gao et } \\
\text { al., 2008) }\end{array}$ \\
\hline 1653 & 25 & - & 0.0101 & - & - & - & - \\
\hline 1654 & - & - & 0.0066 & - & - & - & - \\
\hline 1655 & - & - & 0.0043 & - & - & - & - \\
\hline 1656 & - & - & 0.0052 & - & - & - & - \\
\hline 1657 & - & - & 0.0004 & - & - & - & - \\
\hline 1658 & - & - & 0.0030 & - & - & - & - \\
\hline 1659 & - & - & 0.0011 & - & - & - & - \\
\hline 1660 & 340 & - & 0.0157 & - & - & - & - \\
\hline 1661 & 255 & 0.341 & 0.0316 & - & - & - & - \\
\hline 1662 & 170 & - & - & 0.013 & - & - & - \\
\hline 1663 & 85 & 0.292 & 0.0024 & 0.004 & - & - & - \\
\hline 1664 & 130 & 0.146 & - & 0.001 & - & - & - \\
\hline 1665 & 100 & - & 0.0059 & - & - & - & - \\
\hline 1666 & 65 & 0.112 & 0.0079 & - & - & - & - \\
\hline 1667 & 30 & 0.089 & 0.0161 & 0.017 & - & - & - \\
\hline 1668 & - & - & 0.0461 & 0.048 & - & - & - \\
\hline 1669 & - & - & - & 0.011 & - & - & - \\
\hline 1670 & - & - & - & 0.002 & - & - & - \\
\hline 1671 & - & - & 0.0018 & - & - & - & - \\
\hline 1672 & 200 & - & 0.0011 & - & - & - & - \\
\hline 1673 & 150 & 0.168 & 0.0446 & 0.07 & - & - & 16.13 \\
\hline 1674 & 100 & - & 0.0539 & 0.128 & - & - & - \\
\hline 1675 & 50 & - & 0.0065 & 0.049 & - & - & - \\
\hline 1676 & - & - & 0.0036 & 0.018 & - & - & - \\
\hline 1677 & - & - & - & 0.007 & - & - & - \\
\hline 1678 & - & - & 0.0001 & 0.001 & - & - & - \\
\hline 1679 & - & - & 0.0051 & - & - & - & - \\
\hline 1680 & 280 & 0.478 & 0.0008 & 0.021 & - & - & - \\
\hline 1681 & 210 & - & 0.0001 & 0.018 & - & - & - \\
\hline 1682 & 140 & - & 0.0007 & 0.007 & - & - & - \\
\hline 1683 & 70 & - & 0.0065 & 0.002 & - & - & - \\
\hline 1684 & - & - & 0.0009 & 0.001 & - & - & - \\
\hline 1685 & - & - & 0.0019 & - & - & - & - \\
\hline 1686 & - & - & 0.0080 & 0.006 & - & - & - \\
\hline 1687 & - & - & 0.0020 & 0.003 & - & - & - \\
\hline 1688 & - & - & - & 0.002 & - & - & - \\
\hline 1689 & - & - & 0.0010 & 0.001 & - & - & - \\
\hline 1690 & - & - & - & - & - & - & - \\
\hline 1691 & - & - & 0.0005 & - & - & - & - \\
\hline 1692 & - & - & 0.0106 & - & - & - & - \\
\hline 1693 & 140 & 0.151 & 0.0563 & - & - & - & 27.1 \\
\hline 1694 & 285 & - & 0.0777 & 0.105 & - & - & - \\
\hline 1695 & 205 & - & 0.1405 & 0.158 & - & - & - \\
\hline 1696 & 105 & 0.104 & 0.0395 & 0.171 & - & - & - \\
\hline 1697 & 45 & - & 0.0028 & 0.075 & - & - & - \\
\hline 1698 & - & - & - & 0.033 & - & - & - \\
\hline 1699 & - & - & 0.0022 & 0.009 & - & - & - \\
\hline 1700 & - & - & 0.0026 & 0.004 & - & - & - \\
\hline 1701 & - & - & 0.0010 & 0.001 & - & - & - \\
\hline 1702 & - & - & - & 0.002 & - & - & - \\
\hline 1703 & - & - & 0.0003 & - & - & - & - \\
\hline 1704 & - & - & - & 0.005 & - & - & - \\
\hline 1705 & - & - & 0.0126 & 0.002 & - & - & - \\
\hline
\end{tabular}


Table D1. Continued.

\begin{tabular}{|c|c|c|c|c|c|c|c|}
\hline \multirow[t]{2}{*}{ Year } & N.H. DVI & $\begin{array}{l}\text { N.H. AOD } \\
\text { from paintings }\end{array}$ & AOD & AOD & AOD & AOD & $\begin{array}{c}\text { Sulfate } \\
\text { aerosols (Tg) }\end{array}$ \\
\hline & $\begin{array}{c}\text { (Lamb, 1970, } \\
1977,1983)\end{array}$ & $\begin{array}{l}\text { (this } \\
\text { study) }\end{array}$ & $\begin{array}{l}\text { (Robertson } \\
\text { et al., 2001) }\end{array}$ & $\begin{array}{c}\text { Crowley and } \\
\text { Unterman (2013) }\end{array}$ & $\begin{array}{c}\text { (Sato et } \\
\text { al., 1993) }\end{array}$ & $\begin{array}{c}\text { (Stothers, } \\
\text { 1996, 2001) }\end{array}$ & $\begin{array}{c}\text { (Gao et } \\
\text { al., 2008) }\end{array}$ \\
\hline 1706 & - & - & 0.0040 & 0.004 & - & - & - \\
\hline 1707 & 300 & - & - & 0.001 & - & - & - \\
\hline 1708 & 225 & - & - & - & - & - & - \\
\hline 1709 & 150 & - & - & - & - & - & - \\
\hline 1710 & 75 & 0.104 & 0.0031 & - & - & - & - \\
\hline 1711 & - & - & 0.0078 & - & - & - & 3.86 \\
\hline 1712 & 80 & - & 0.0022 & - & - & - & - \\
\hline 1713 & 60 & - & 0.0207 & - & - & - & - \\
\hline 1714 & 40 & - & 0.0007 & - & - & - & - \\
\hline 1715 & 20 & - & 0.0025 & 0.001 & - & - & - \\
\hline 1716 & - & - & 0.0027 & - & - & - & - \\
\hline 1717 & 120 & - & 0.0003 & - & - & - & - \\
\hline 1718 & 90 & 0.13 & 0.0006 & - & - & - & - \\
\hline 1719 & 60 & - & 0.0023 & - & - & - & 31.48 \\
\hline 1720 & 30 & 0.058 & 0.0066 & 0.005 & - & - & - \\
\hline 1721 & 100 & - & 0.0091 & 0.001 & - & - & - \\
\hline 1722 & 75 & - & 0.0042 & - & - & - & - \\
\hline 1723 & 50 & - & 0.0011 & 0.003 & - & - & - \\
\hline 1724 & 55 & - & - & 0.001 & - & - & - \\
\hline 1725 & 15 & - & - & - & - & - & - \\
\hline 1726 & 15 & - & 0.0032 & - & - & - & - \\
\hline 1727 & 15 & 0.087 & 0.0112 & - & - & - & - \\
\hline 1728 & 15 & - & 0.0270 & - & - & - & - \\
\hline 1729 & 15 & - & 0.0043 & - & - & - & 12.02 \\
\hline 1730 & 160 & 0.126 & 0.0319 & - & - & - & - \\
\hline 1731 & 130 & - & 0.0854 & 0.024 & - & - & - \\
\hline 1732 & 90 & - & 0.0088 & 0.008 & - & - & - \\
\hline 1733 & 50 & - & - & 0.002 & - & - & - \\
\hline 1734 & - & - & 0.0002 & - & - & - & - \\
\hline 1735 & - & - & 0.0012 & - & - & - & - \\
\hline 1736 & - & - & 0.0006 & - & - & - & - \\
\hline 1737 & - & - & 0.0044 & - & - & - & - \\
\hline 1738 & - & - & 0.0122 & - & - & - & 3.34 \\
\hline 1739 & - & - & 0.0167 & 0.017 & - & - & - \\
\hline 1740 & - & - & 0.0359 & 0.035 & - & - & - \\
\hline 1741 & - & - & 0.0032 & 0.008 & - & - & - \\
\hline 1742 & - & - & - & 0.002 & - & - & - \\
\hline 1743 & - & - & - & - & - & - & - \\
\hline 1744 & 60 & - & 0.0012 & - & - & - & - \\
\hline 1745 & 45 & - & 0.0079 & - & - & - & - \\
\hline 1746 & 30 & 0.067 & 0.0009 & - & - & - & - \\
\hline 1747 & 15 & - & 0.0200 & 0.005 & - & - & - \\
\hline 1748 & - & - & 0.0001 & 0.001 & - & - & - \\
\hline 1749 & - & - & 0.0154 & - & - & - & - \\
\hline 1750 & - & - & - & - & - & - & - \\
\hline 1751 & - & - & 0.0083 & - & - & - & - \\
\hline 1752 & 200 & - & 0.0026 & - & - & - & - \\
\hline 1753 & 150 & 0.167 & 0.0018 & - & - & - & - \\
\hline 1754 & 160 & - & 0.0018 & - & - & - & - \\
\hline 1755 & 255 & - & 0.0113 & - & - & - & 7.96 \\
\hline 1756 & 150 & - & 0.0063 & - & - & - & - \\
\hline 1757 & 95 & - & 0.0045 & - & - & - & - \\
\hline 1758 & 40 & - & 0.0077 & - & - & - & - \\
\hline
\end{tabular}


Table D1. Continued.

\begin{tabular}{|c|c|c|c|c|c|c|c|}
\hline \multirow[t]{2}{*}{ Year } & N.H. DVI & $\begin{array}{l}\text { N.H. AOD } \\
\text { from paintings }\end{array}$ & AOD & AOD & AOD & AOD & $\begin{array}{c}\text { Sulfate } \\
\text { aerosols (Tg) }\end{array}$ \\
\hline & $\begin{array}{c}\text { (Lamb, 1970, } \\
1977,1983)\end{array}$ & $\begin{array}{l}\text { (this } \\
\text { study) }\end{array}$ & $\begin{array}{l}\text { (Robertson } \\
\text { et al., 2001) }\end{array}$ & $\begin{array}{c}\text { Crowley and } \\
\text { Unterman (2013) }\end{array}$ & $\begin{array}{c}\text { (Sato et } \\
\text { al., 1993) }\end{array}$ & $\begin{array}{c}\text { (Stothers, } \\
\text { 1996, 2001) }\end{array}$ & $\begin{array}{c}\text { (Gao et } \\
\text { al., 2008) }\end{array}$ \\
\hline 1759 & 80 & - & 0.0029 & - & - & - & - \\
\hline 1760 & 110 & 0.138 & 0.0015 & 0.005 & - & - & - \\
\hline 1761 & 77 & - & 0.0072 & 0.001 & - & - & 12.91 \\
\hline 1762 & 45 & - & 0.0116 & 0.024 & - & - & - \\
\hline 1763 & 13 & - & 0.0074 & 0.007 & - & - & - \\
\hline 1764 & - & - & 0.0028 & 0.002 & - & - & - \\
\hline 1765 & - & - & 0.0028 & - & - & - & - \\
\hline 1766 & - & - & 0.0136 & - & - & - & - \\
\hline 1767 & - & - & 0.0035 & - & - & - & - \\
\hline 1768 & - & - & 0.0002 & - & - & - & - \\
\hline 1769 & - & - & 0.0056 & - & - & - & - \\
\hline 1770 & - & - & 0.0041 & - & - & - & - \\
\hline 1771 & - & - & 0.0012 & - & - & - & - \\
\hline 1772 & 50 & 0.067 & 0.0029 & 0.006 & - & - & - \\
\hline 1773 & 37 & - & 0.0034 & 0.002 & - & - & - \\
\hline 1774 & 25 & - & 0.0003 & - & - & - & - \\
\hline 1775 & 13 & - & 0.0051 & - & - & - & - \\
\hline 1776 & - & - & 0.0032 & - & - & - & - \\
\hline 1777 & - & - & 0.0002 & - & - & - & - \\
\hline 1778 & - & - & 0.0011 & 0.005 & - & - & - \\
\hline 1779 & 180 & - & 0.0015 & 0.006 & - & - & - \\
\hline 1780 & 135 & - & 0.0019 & 0.001 & - & - & - \\
\hline 1781 & 90 & 0.094 & 0.0092 & - & - & - & - \\
\hline 1782 & 45 & 0.115 & 0.0106 & - & - & - & - \\
\hline 1783 & 400 & - & 0.1643 & 0.009 & - & - & 92.96 \\
\hline 1784 & 300 & 0.3 & 0.1354 & 0.042 & - & - & - \\
\hline 1785 & 200 & - & 0.0005 & 0.01 & - & - & - \\
\hline 1786 & 160 & - & 0.0021 & 0.002 & - & - & - \\
\hline 1787 & 45 & - & 0.0080 & - & - & - & - \\
\hline 1788 & 30 & - & 0.0035 & 0.011 & - & - & - \\
\hline 1789 & 15 & - & 0.0011 & 0.003 & - & - & - \\
\hline 1790 & - & - & 0.0022 & 0.001 & - & - & - \\
\hline 1791 & - & - & - & - & - & - & - \\
\hline 1792 & - & - & 0.0013 & - & - & - & - \\
\hline 1793 & - & - & 0.0292 & - & - & - & - \\
\hline 1794 & - & - & 0.0177 & - & - & - & 1.88 \\
\hline 1795 & 120 & 0.098 & 0.0043 & - & - & - & - \\
\hline 1796 & 130 & - & 0.0017 & 0.018 & - & - & 6.7 \\
\hline 1797 & 90 & - & 0.0041 & 0.006 & - & - & - \\
\hline 1798 & 50 & - & 0.0048 & 0.001 & - & - & - \\
\hline 1799 & 130 & - & 0.0060 & - & - & - & - \\
\hline 1800 & 90 & - & 0.0010 & - & - & - & - \\
\hline 1801 & 60 & 0.081 & 0.0031 & 0.012 & - & - & - \\
\hline 1802 & 30 & - & 0.0036 & 0.004 & - & - & - \\
\hline 1803 & - & - & 0.0047 & 0.001 & - & - & - \\
\hline 1804 & - & - & 0.0019 & 0.018 & - & - & - \\
\hline 1805 & - & - & 0.0043 & 0.006 & - & - & - \\
\hline 1806 & - & - & 0.0011 & 0.001 & - & - & - \\
\hline 1807 & - & - & 0.0021 & - & - & - & - \\
\hline 1808 & - & - & - & - & - & - & - \\
\hline 1809 & - & - & 0.1391 & 0.198 & - & - & 53.74 \\
\hline 1810 & - & - & 0.2308 & 0.18 & - & - & - \\
\hline 1811 & 80 & - & 0.0537 & 0.067 & - & - & - \\
\hline
\end{tabular}


Table D1. Continued.

\begin{tabular}{|c|c|c|c|c|c|c|c|}
\hline \multirow[t]{2}{*}{ Year } & N.H. DVI & $\begin{array}{l}\text { N.H. AOD } \\
\text { from paintings }\end{array}$ & AOD & AOD & AOD & AOD & $\begin{array}{c}\text { Sulfate } \\
\text { aerosols (Tg) }\end{array}$ \\
\hline & $\begin{array}{c}\text { (Lamb, 1970, } \\
1977,1983)\end{array}$ & $\begin{array}{l}\text { (this } \\
\text { study) }\end{array}$ & $\begin{array}{l}\text { (Robertson } \\
\text { et al., 2001) }\end{array}$ & $\begin{array}{c}\text { Crowley and } \\
\text { Unterman (2013) }\end{array}$ & $\begin{array}{l}\text { (Sato et } \\
\text { al., 1993) }\end{array}$ & $\begin{array}{c}\text { (Stothers, } \\
1996,2001)\end{array}$ & $\begin{array}{c}\text { (Gao et } \\
\text { al., 2008) }\end{array}$ \\
\hline 1812 & 180 & 0.199 & 0.0055 & 0.025 & - & - & - \\
\hline 1813 & 170 & 0.181 & 0.0019 & 0.009 & - & - & - \\
\hline 1814 & 170 & 0.142 & 0.0008 & - & - & - & - \\
\hline 1815 & 695 & - & 0.3351 & 0.199 & - & - & 109.72 \\
\hline 1816 & 490 & 0.6 & 0.3260 & 0.364 & - & - & - \\
\hline 1817 & 375 & 0.379 & 0.0798 & 0.194 & - & - & - \\
\hline 1818 & 195 & 0.33 & 0.0024 & 0.073 & - & - & - \\
\hline 1819 & 30 & 0.108 & 0.0015 & 0.027 & - & - & - \\
\hline 1820 & 15 & 0.062 & 0.0023 & 0.003 & - & - & - \\
\hline 1821 & - & - & 0.0070 & - & - & - & - \\
\hline 1822 & 200 & - & 0.0075 & - & - & - & - \\
\hline 1823 & 150 & - & 0.0002 & - & - & - & - \\
\hline 1824 & 100 & - & 0.0035 & - & - & - & - \\
\hline 1825 & 70 & 0.104 & 0.0003 & - & - & - & - \\
\hline 1826 & 80 & 0.15 & 0.0055 & - & - & - & - \\
\hline 1827 & 65 & 0.143 & 0.0003 & - & - & - & - \\
\hline 1828 & 50 & 0.147 & 0.0040 & - & - & - & - \\
\hline 1829 & 75 & 0.147 & 0.0005 & - & - & - & - \\
\hline 1830 & 50 & 0.069 & 0.0062 & - & - & - & - \\
\hline 1831 & 200 & 0.293 & 0.0570 & 0.01 & - & - & 16.97 \\
\hline 1832 & 130 & 0.284 & 0.0570 & 0.098 & - & - & - \\
\hline 1833 & 80 & 0.16 & - & 0.048 & - & - & - \\
\hline 1834 & 40 & 0.059 & 0.0081 & 0.018 & - & - & - \\
\hline 1835 & 525 & 0.52 & 0.1300 & 0.127 & - & - & 40.16 \\
\hline 1836 & 450 & - & 0.1527 & 0.116 & - & - & - \\
\hline 1837 & 375 & - & 0.0218 & 0.042 & - & - & - \\
\hline 1838 & 300 & - & 0.0091 & 0.015 & - & - & - \\
\hline 1839 & 225 & 0.178 & - & 0.006 & - & - & - \\
\hline 1840 & 150 & 0.185 & 0.0004 & 0.004 & - & - & - \\
\hline 1841 & 75 & 0.11 & 0.0030 & 0.001 & - & - & - \\
\hline 1842 & - & - & 0.0012 & - & - & - & - \\
\hline 1843 & - & - & 0.0007 & 0.004 & - & - & - \\
\hline 1844 & - & - & 0.0022 & 0.001 & - & - & - \\
\hline 1845 & 100 & 0.145 & 0.0071 & - & - & - & - \\
\hline 1846 & 205 & - & 0.0036 & 0.006 & - & - & - \\
\hline 1847 & 140 & - & 0.0006 & 0.002 & - & - & - \\
\hline 1848 & 90 & - & 0.0029 & - & - & - & - \\
\hline 1849 & 30 & - & 0.0039 & - & - & - & - \\
\hline 1850 & - & - & - & - & 0.0036 & - & - \\
\hline 1851 & - & - & - & - & 0.0025 & - & - \\
\hline 1852 & - & - & 0.0017 & - & 0.0014 & - & - \\
\hline 1853 & - & - & 0.0075 & - & 0.0006 & - & - \\
\hline 1854 & - & - & 0.0032 & 0.009 & 0.0003 & - & - \\
\hline 1855 & - & - & 0.0043 & 0.004 & 0.0020 & - & - \\
\hline 1856 & 140 & - & 0.0033 & 0.001 & 0.0387 & - & - \\
\hline 1857 & 105 & - & 0.0014 & - & 0.0602 & - & - \\
\hline 1858 & 70 & 0.098 & 0.0013 & - & 0.0290 & - & - \\
\hline 1859 & 35 & 0.083 & 0.0001 & - & 0.0112 & - & - \\
\hline 1860 & - & - & - & 0.003 & 0.0046 & - & - \\
\hline 1861 & 160 & 0.164 & 0.0077 & 0.002 & 0.0034 & - & 4.23 \\
\hline 1862 & 120 & - & 0.0075 & 0.054 & 0.0137 & - & - \\
\hline 1863 & 80 & - & 0.0063 & 0.033 & 0.0100 & - & - \\
\hline 1864 & 40 & 0.081 & 0.0067 & 0.012 & 0.0046 & - & - \\
\hline
\end{tabular}


Table D1. Continued.

\begin{tabular}{|c|c|c|c|c|c|c|c|}
\hline \multirow[t]{2}{*}{ Year } & N.H. DVI & $\begin{array}{c}\text { N.H. AOD } \\
\text { from paintings }\end{array}$ & AOD & AOD & AOD & AOD & $\begin{array}{c}\text { Sulfate } \\
\text { aerosols (Tg) }\end{array}$ \\
\hline & $\begin{array}{c}\text { (Lamb, 1970, } \\
1977,1983)\end{array}$ & $\begin{array}{l}\text { (this } \\
\text { study) }\end{array}$ & $\begin{array}{l}\text { (Robertson } \\
\text { et al., 2001) }\end{array}$ & $\begin{array}{c}\text { Crowley and } \\
\text { Unterman (2013) }\end{array}$ & $\begin{array}{c}\text { (Sato et } \\
\text { al., 1993) }\end{array}$ & $\begin{array}{c}\text { (Stothers, } \\
\text { 1996, 2001) }\end{array}$ & $\begin{array}{c}\text { (Gao et } \\
\text { al., 2008) }\end{array}$ \\
\hline 1865 & - & - & 0.0037 & 0.005 & 0.0020 & - & - \\
\hline 1866 & - & - & 0.0021 & 0.001 & 0.0008 & - & - \\
\hline 1867 & - & - & 0.0018 & - & 0.0004 & - & - \\
\hline 1868 & 160 & 0.204 & 0.0020 & - & 0.0002 & - & - \\
\hline 1869 & 120 & 0.196 & 0.0013 & - & 0.0006 & - & - \\
\hline 1870 & 80 & - & 0.0084 & - & 0.0006 & - & - \\
\hline 1871 & 40 & 0.097 & 0.0009 & - & 0.0006 & - & - \\
\hline 1872 & - & - & 0.0091 & 0.001 & 0.0013 & - & - \\
\hline 1873 & - & - & 0.0033 & 0.008 & 0.0030 & - & - \\
\hline 1874 & - & - & 0.0035 & 0.002 & 0.0020 & - & - \\
\hline 1875 & 120 & 0.241 & 0.0012 & 0.01 & 0.0013 & - & - \\
\hline 1876 & 90 & - & 0.0102 & 0.003 & 0.0062 & - & - \\
\hline 1877 & 60 & - & 0.0130 & 0.001 & 0.0053 & - & - \\
\hline 1878 & 30 & 0.143 & 0.0023 & - & 0.0032 & - & - \\
\hline 1879 & - & - & 0.0009 & - & 0.0020 & - & - \\
\hline 1880 & - & - & - & - & 0.0011 & - & - \\
\hline 1881 & - & - & - & - & 0.0007 & - & - \\
\hline 1882 & - & - & - & - & 0.0006 & - & - \\
\hline 1883 & 400 & 0.56 & 0.0410 & 0.02 & 0.0473 & 0.096 & 21.87 \\
\hline 1884 & 300 & 0.46 & 0.0897 & 0.157 & 0.1429 & 0.192 & - \\
\hline 1885 & 240 & 0.361 & 0.0138 & 0.073 & 0.0635 & 0.071 & - \\
\hline 1886 & 170 & 0.37 & 0.0302 & 0.045 & 0.0364 & 0.026 & 1.93 \\
\hline 1887 & 50 & 0.21 & 0.0325 & 0.016 & 0.0371 & - & - \\
\hline 1888 & 170 & 0.31 & 0.0036 & 0.004 & 0.0219 & - & - \\
\hline 1889 & 125 & - & 0.0019 & - & 0.0285 & - & - \\
\hline 1890 & 85 & 0.132 & 0.0031 & 0.004 & 0.0391 & 0.026 & - \\
\hline 1891 & 45 & 0.101 & 0.0128 & 0.001 & 0.0300 & 0.048 & - \\
\hline 1892 & 20 & 0.094 & 0.0090 & 0.004 & 0.0217 & 0.018 & - \\
\hline 1893 & 15 & 0.108 & 0.0047 & 0.001 & 0.0094 & - & - \\
\hline 1894 & 10 & 0.069 & 0.0007 & - & 0.0035 & - & - \\
\hline 1895 & 5 & - & 0.0005 & - & 0.0014 & - & - \\
\hline 1896 & - & - & 0.0011 & - & 0.0183 & - & - \\
\hline 1897 & - & - & 0.0001 & - & 0.0169 & - & - \\
\hline 1898 & 30 & 0.084 & 0.0041 & 0.007 & 0.0121 & - & - \\
\hline 1899 & 25 & 0.084 & 0.0014 & 0.002 & 0.0046 & - & - \\
\hline 1900 & 15 & 0.13 & 0.0027 & - & 0.0018 & - & - \\
\hline 1901 & 5 & - & 0.0021 & - & 0.0007 & - & - \\
\hline 1902 & 180 & 0.27 & 0.0094 & 0.004 & 0.0202 & 0.014 & 3.77 \\
\hline 1903 & 135 & - & 0.0478 & 0.069 & 0.0715 & 0.118 & - \\
\hline 1904 & 90 & 0.118 & 0.0092 & 0.038 & 0.0318 & 0.061 & - \\
\hline 1905 & 45 & - & 0.0032 & 0.014 & 0.0126 & - & - \\
\hline 1906 & - & 0.17 & 0.0049 & 0.005 & 0.0073 & - & - \\
\hline 1907 & 60 & 0.2655 & 0.0078 & 0.013 & 0.0092 & 0.01 & - \\
\hline 1908 & 45 & 0.2 & 0.0056 & 0.006 & 0.0103 & 0.004 & - \\
\hline 1909 & 30 & 0.13 & - & 0.001 & 0.0040 & - & - \\
\hline 1910 & 15 & - & 0.0008 & - & 0.0031 & - & - \\
\hline 1911 & - & - & 0.0518 & - & 0.0017 & - & - \\
\hline 1912 & 60 & 0.163 & 0.0161 & 0.031 & 0.0193 & 0.028 & 11.04 \\
\hline 1913 & 45 & 0.16 & 0.0120 & 0.029 & 0.0241 & 0.019 & - \\
\hline 1914 & 30 & 0.168 & 0.0048 & 0.006 & 0.0099 & 0.007 & - \\
\hline 1915 & 15 & 0.106 & 0.0055 & 0.001 & 0.0039 & - & - \\
\hline 1916 & - & 0.177 & 0.0040 & 0.009 & 0.0027 & - & - \\
\hline 1917 & - & 0.122 & 0.0016 & 0.003 & 0.0022 & - & - \\
\hline
\end{tabular}


Table D1. Continued.

\begin{tabular}{|c|c|c|c|c|c|c|c|}
\hline \multirow[t]{2}{*}{ Year } & N.H. DVI & $\begin{array}{l}\text { N.H. AOD } \\
\text { from paintings }\end{array}$ & AOD & AOD & AOD & AOD & $\begin{array}{c}\text { Sulfate } \\
\text { aerosols }(\mathrm{Tg})\end{array}$ \\
\hline & $\begin{array}{c}\text { (Lamb, 1970, } \\
1977,1983)\end{array}$ & $\begin{array}{l}\text { (this } \\
\text { study) }\end{array}$ & $\begin{array}{l}\text { (Robertson } \\
\text { et al., 2001) }\end{array}$ & $\begin{array}{c}\text { Crowley and } \\
\text { Unterman (2013) }\end{array}$ & $\begin{array}{c}\text { (Sato et } \\
\text { al., 1993) }\end{array}$ & $\begin{array}{c}\text { (Stothers, } \\
1996,2001)\end{array}$ & $\begin{array}{c}\text { (Gao et } \\
\text { al., 2008) }\end{array}$ \\
\hline 1918 & - & 0.12 & 0.0036 & 0.001 & 0.0020 & - & - \\
\hline 1919 & - & 0.195 & 0.0072 & - & 0.0020 & - & - \\
\hline 1920 & - & 0.16 & 0.0014 & - & 0.0094 & - & - \\
\hline 1921 & - & 0.156 & 0.0012 & 0.005 & 0.0077 & - & - \\
\hline 1922 & - & 0.2 & 0.0052 & 0.001 & 0.0029 & 0.008 & - \\
\hline 1923 & - & 0.13 & 0.0031 & - & 0.0011 & 0.004 & - \\
\hline 1924 & - & - & 0.0102 & 0.011 & 0.0034 & - & - \\
\hline 1925 & - & 0.15 & 0.0106 & 0.005 & 0.0029 & - & 11.15 \\
\hline 1926 & - & - & 0.0126 & 0.001 & 0.0023 & - & - \\
\hline 1927 & - & 0.175 & 0.0029 & - & 0.0015 & - & - \\
\hline 1928 & - & 0.195 & 0.0036 & - & 0.0053 & 0.002 & - \\
\hline 1929 & - & - & 0.0029 & 0.002 & 0.0098 & 0.014 & - \\
\hline 1930 & - & - & 0.0002 & 0.002 & 0.0062 & - & - \\
\hline 1931 & - & - & 0.0075 & 0.006 & 0.0047 & - & - \\
\hline 1932 & - & 0.161 & 0.0005 & 0.01 & 0.0082 & 0.012 & - \\
\hline 1933 & - & 0.172 & 0.0026 & 0.003 & 0.0067 & 0.002 & - \\
\hline 1934 & - & - & 0.0028 & 0.001 & 0.0038 & - & - \\
\hline 1935 & - & 0.116 & 0.0058 & - & 0.0042 & - & - \\
\hline 1936 & - & 0.122 & 0.0021 & - & 0.0033 & - & - \\
\hline 1937 & - & - & 0.0278 & - & 0.0028 & - & - \\
\hline 1938 & - & 0.136 & 0.0044 & - & 0.0049 & - & - \\
\hline 1939 & - & - & 0.0054 & - & 0.0041 & - & - \\
\hline 1940 & - & 0.094 & 0.0004 & - & 0.0032 & - & - \\
\hline 1941 & - & - & 0.0050 & - & 0.0019 & - & - \\
\hline 1942 & - & - & 0.0036 & - & 0.0042 & - & - \\
\hline 1943 & - & 0.094 & 0.0728 & - & 0.0044 & - & 6.61 \\
\hline 1944 & - & 0.21 & 0.0499 & - & 0.0024 & - & - \\
\hline 1945 & - & - & 0.0012 & - & 0.0022 & - & - \\
\hline 1946 & - & - & 0.0033 & - & 0.0018 & - & - \\
\hline 1947 & - & - & 0.0056 & - & 0.0023 & - & - \\
\hline 1948 & - & - & 0.0033 & - & 0.0017 & - & - \\
\hline 1949 & - & - & 0.0029 & - & 0.0033 & - & - \\
\hline 1950 & - & - & 0.0027 & - & 0.0029 & - & - \\
\hline 1951 & - & - & 0.0507 & - & 0.0020 & - & - \\
\hline 1952 & - & 0.167 & 0.0559 & - & 0.0037 & - & - \\
\hline 1953 & - & 0.268 & 0.0056 & - & 0.0034 & - & - \\
\hline 1954 & - & - & 0.0006 & - & 0.0036 & - & - \\
\hline 1955 & - & - & 0.0038 & - & 0.0018 & - & - \\
\hline 1956 & - & - & 0.0068 & 0.005 & 0.0011 & - & - \\
\hline 1957 & - & - & 0.0053 & 0.001 & 0.0005 & - & - \\
\hline 1958 & - & 0.293 & 0.0008 & - & 0.0003 & - & - \\
\hline 1959 & - & - & 0.0029 & - & 0.0002 & - & - \\
\hline 1960 & - & - & 0.0005 & - & 0.0046 & - & - \\
\hline 1961 & - & - & 0.0053 & - & 0.0108 & - & - \\
\hline 1962 & - & - & 0.0024 & - & 0.0133 & 0.012 & - \\
\hline 1963 & 160 & - & 0.0502 & 0.04 & 0.0460 & 0.066 & 17 \\
\hline 1964 & 120 & - & 0.0389 & 0.055 & 0.0717 & 0.051 & - \\
\hline 1965 & 80 & - & 0.0149 & 0.03 & 0.0432 & 0.031 & - \\
\hline 1966 & 40 & - & 0.0027 & 0.01 & 0.0232 & 0.014 & - \\
\hline 1967 & 31.4 & 0.138 & 0.0053 & 0.003 & 0.0145 & 0.019 & - \\
\hline 1968 & 60.7 & 0.32 & 0.0164 & 0.001 & 0.0274 & 0.011 & - \\
\hline 1969 & 40 & - & 0.0388 & - & 0.0344 & 0.006 & - \\
\hline 1970 & 32.4 & - & 0.0275 & - & 0.0166 & 0.006 & - \\
\hline
\end{tabular}


Table D1. Continued.

\begin{tabular}{|c|c|c|c|c|c|c|c|}
\hline \multirow[t]{2}{*}{ Year } & N.H. DVI & $\begin{array}{l}\text { N.H. AOD } \\
\text { from paintings }\end{array}$ & AOD & AOD & AOD & AOD & $\begin{array}{c}\text { Sulfate } \\
\text { aerosols (Tg) }\end{array}$ \\
\hline & $\begin{array}{c}\text { (Lamb, 1970, } \\
1977,1983)\end{array}$ & $\begin{array}{l}\text { (this } \\
\text { study) }\end{array}$ & $\begin{array}{l}\text { (Robertson } \\
\text { et al., 2001) }\end{array}$ & $\begin{array}{c}\text { Crowley and } \\
\text { Unterman (2013) }\end{array}$ & $\begin{array}{l}\text { (Sato et } \\
\text { al., 1993) }\end{array}$ & $\begin{array}{c}\text { (Stothers, } \\
\text { 1996, 2001) }\end{array}$ & $\begin{array}{c}\text { (Gao et } \\
\text { al., 2008) }\end{array}$ \\
\hline 1971 & 23.7 & - & 0.0141 & - & 0.0065 & 0.015 & - \\
\hline 1972 & 9.5 & - & 0.0135 & - & 0.0039 & 0.008 & - \\
\hline 1973 & 9.3 & - & 0.0047 & - & 0.0078 & 0.001 & - \\
\hline 1974 & 56.1 & - & 0.0055 & - & 0.0127 & 0.007 & - \\
\hline 1975 & 41 & - & 0.0071 & 0.024 & 0.0301 & 0.024 & - \\
\hline 1976 & 67 & - & 0.0080 & 0.015 & 0.0136 & 0.007 & 4.72 \\
\hline 1977 & 45.4 & - & - & 0.006 & 0.0051 & 0.003 & - \\
\hline 1978 & 25.8 & - & 0.0051 & 0.002 & 0.0075 & 0.001 & - \\
\hline 1979 & 25.4 & 0.19 & 0.0019 & 0.001 & 0.0092 & - & - \\
\hline 1980 & 51 & - & 0.0010 & - & 0.0047 & - & - \\
\hline 1981 & 41 & - & 0.0098 & - & 0.0050 & - & - \\
\hline 1982 & 366.1 & - & 0.0492 & 0.048 & 0.0525 & - & 14 \\
\hline 1983 & 267.2 & - & 0.0370 & 0.079 & 0.0752 & - & - \\
\hline 1984 & 171.1 & 0.19 & - & 0.03 & 0.0302 & - & - \\
\hline 1985 & 85 & - & - & 0.011 & 0.0126 & - & - \\
\hline 1986 & - & - & - & 0.004 & 0.0136 & - & - \\
\hline 1987 & - & - & - & - & 0.0103 & - & - \\
\hline 1988 & - & - & - & - & 0.0076 & - & - \\
\hline 1989 & - & - & - & - & 0.0061 & - & - \\
\hline 1990 & - & - & - & - & 0.0061 & - & - \\
\hline 1991 & - & 0.15 & - & 0.037 & 0.0539 & - & 30.1 \\
\hline 1992 & - & - & - & 0.131 & 0.1211 & - & - \\
\hline 1993 & - & - & - & 0.053 & 0.0490 & - & - \\
\hline 1994 & - & - & - & 0.02 & 0.0200 & - & - \\
\hline 1995 & - & - & - & 0.007 & 0.0096 & - & - \\
\hline 1996 & - & 0.22 & - & 0.001 & 0.0065 & - & - \\
\hline 1997 & - & - & - & - & 0.0052 & - & - \\
\hline 1998 & - & - & - & - & 0.0028 & - & - \\
\hline 1999 & - & - & - & - & 0.0021 & - & - \\
\hline 2000 & - & - & - & - & 0.0021 & - & - \\
\hline
\end{tabular}

